\title{
Regioselective C-H Activation of Substituted Pyridines and other Azines using Mg- and Zn-TMP-Bases
}

\author{
Moritz Balkenhohl \\ Paul Knochel* (iD) \\ Department of Chemistry, Ludwig-Maximilians-Universität \\ München, Butenandtstraße 5-13, Haus F, 81377 München, \\ Germany \\ Paul.Knochel@cup.uni-muenchen.de
}

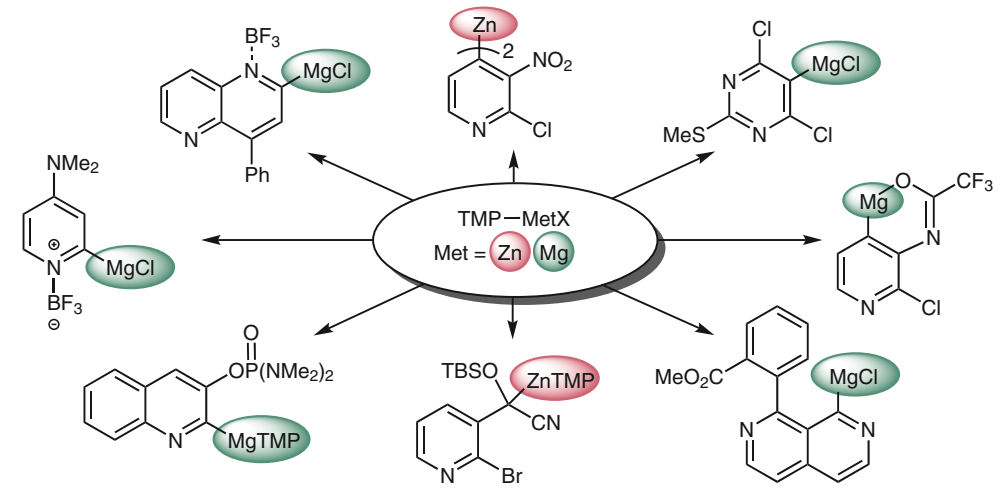

Received: 31.01.2018

Accepted: 04.03.2018

Published online: 19.03 .2018

DOI: 10.1055/s-0036-1591966; Art ID: so-2018-d0014-r

License terms: CC $0 \$$

Abstract The metalation of substituted pyridines, diazines and related $\mathrm{N}$-heterocycles using TMPMgCl$\cdot \mathrm{LiCl}, \mathrm{TMP}_{2} \mathrm{Mg} \cdot 2 \mathrm{LiCl}, \mathrm{TMPZnCl} \cdot \mathrm{LiCl}$ or $\mathrm{TMP}_{2} \mathrm{Zn} \cdot 2 \mathrm{LiCl}_{2} \cdot 2 \mathrm{MgCl}_{2}(\mathrm{TMP}=2,2,6$,6-tetramethylpiperidyl) in the presence or absence of a Lewis acid is reviewed.

Contents

1 Introduction

2 Magnesiation of Pyridines and Related Azines

2.1 Magnesiations using TMPMgCl.LiCl

2.2 Magnesiations using $\mathrm{TMP}_{2} \mathrm{Mg} \cdot 2 \mathrm{LiCl}$ and Related Bases

2.3 $\mathrm{BF}_{3} \cdot \mathrm{OEt}_{2}$ Promoted Metalations of Pyridines

3 Zincation of Pyridines and Related Azines using TMPZnCl.LiCl and $\mathrm{TMP}_{2} \mathrm{Zn} \cdot 2 \mathrm{LiCl} \cdot 2 \mathrm{MgCl}_{2}$

4 Metalation of Pyridines using other TMP-Bases

5 Magnesiation and Zincation of Diazines

6 Conclusion

Key words azines, metalation, $N$-heterocycles, pyridine, TMP bases

\section{Introduction}

The regioselective functionalization of azines, especially pyridines, is an important synthetic challenge because of the importance of these $\mathrm{N}$-heterocycles as pharmaceuticals and agrochemicals. ${ }^{1}$ The use of lithium bases for achieving regioselective lithiations has been pioneered by Snieckus, ${ }^{2}$ Schlosser, $^{3}$ Quéginer $^{4}$ and Mongin ${ }^{4 \mathrm{~h}-\mathrm{j}, 5}$ as well as Gros. ${ }^{6}$ These powerful bases produce lithiated $\mathrm{N}$-heterocycles, which are often only stable at low temperature, although the performance of such metalations in continuous flow may avoid such low temperatures. ${ }^{7}$ Furthermore, the use of lithium magnesiate or zincate bases pioneered by Mulvey, ${ }^{8}$ Mongin,, $8 \mathrm{~b}, 9$ Uchiyama ${ }^{8 \mathrm{~b}, 9 \mathrm{~b}, \mathrm{e}, \mathrm{g}, \mathrm{l}, 10}$ and Kondo $^{8 \mathrm{~b}, 10 \mathrm{a}-\mathrm{c}, 11}$ has considerably broadened the scope of metalations for the func- tionalizations of pyridines and other azines. Recently, it became clear that highly reactive magnesium and zinc bases can be obtained by mixing sterically hindered magnesium and zinc bases (derived mostly from 2,2,6,6-tetramethylpiperidine (TMP-H)) with $\mathrm{LiCl}^{12}$ The resulting, highly THF-soluble bases ${ }^{13}$ are mostly monomeric and kinetically highly active for the magnesiation and zincation of various functionalized pyridines or sensitive azines. ${ }^{12}$ Furthermore, in such metalations, only magnesiated or zincated heterocycles are produced, which are compatible with a range of functional groups at moderate to low temperatures. In the case of the zincation of azines, either ambient or elevated temperature (up to $120^{\circ} \mathrm{C}$ ) ${ }^{14}$ can be used, offering considerable potential for industrial applications. Since the metalation of azines using magnesiate or zincate bases has already been reported extensively, ${ }^{8-11}$ this review will focus on recent advances describing the most practical and regioselective $\mathrm{C}-\mathrm{H}$ activations ${ }^{15}$ of functionalized pyridines and other azines, using mostly zinc and magnesium TMP-bases. ${ }^{16}$

\section{Magnesiation of Pyridines and Related Azines}

\subsection{Magnesiations using TMPMgCl$\cdot \mathrm{LiCl}(1)$}

Usually, magnesium amides of type $\mathrm{R}_{2} \mathrm{NMgX}$ or $\left(\mathrm{R}_{2} \mathrm{~N}\right)_{2} \mathrm{Mg}$ are aggregated and relatively slow deprotonation reagents, partially because of their moderate solubility. ${ }^{17}$ Mulzer pioneered the use of $\mathrm{TMPMgCl}$ for the magnesiation of an azine. ${ }^{18} \mathrm{~A}$ base with higher activity and higher solubility in THF was obtained by using TMPMgCl with $\mathrm{LiCl}(1$ equiv). Thus, mixing of TMP-H with $i$-PrMgCl-LiCl in THF $\left(25^{\circ} \mathrm{C}, 24 \mathrm{~h}\right.$ ) provides a ca. $1.4 \mathrm{M}$ soluble base TMPMgCl.LiCl (1). ${ }^{12,13}$ 
This base magnesiates a range of functionalized pyridines and quinolines under mild conditions. Since magnesium reagents are produced, there is no need for low temperatures as it is often the case with corresponding lithiations. ${ }^{19,20}$ Thus, the magnesiation of 2-bromoquinoline 2 with TMPMgCl$\cdot \mathrm{LiCl}(\mathbf{1})$ at $-20^{\circ} \mathrm{C}$ for $2 \mathrm{~h}$ provides the orthomagnesiated product 3 (Scheme 1). After bromolysis, the dibromoquinoline 4 is obtained in 65\% yield. ${ }^{21}$ Pyridines bearing less sensitive functional groups, such as 3,5-dibromopyridine (5) or 2,6-dichloropyridine (6), are magnesiated at convenient temperatures $\left(-25^{\circ} \mathrm{C}\right.$ or $\left.25^{\circ} \mathrm{C}\right)$, regioselectively providing the pyridylmagnesium derivatives $\mathbf{7}$ and $\mathbf{8}$. Quenching with various electrophiles, such as $\mathrm{N}, \mathrm{N}$-dimethylformamide (DMF) or 4-methoxybenzaldehyde, affords the polyfunctional pyridines $\mathbf{9}$ and $\mathbf{1 0}$ in $85-92 \%$ yield (Scheme 1). ${ }^{12}$

The last reaction can be readily scaled up to a 100 mmol-scale with no yield loss. ${ }^{22}$ Aminopyridines are converted into the corresponding trifluoroacetamides such as 11. Deprotonation of the amide function with $\mathrm{MeMgCl}$ and ring-magnesiation with $\mathrm{TMPMgCl} \cdot \mathrm{LiCl}$ (1) furnishes the Grignard reagent 12, which, after a transmetalation with $\mathrm{ZnCl}_{2}$ and Negishi cross-coupling, ${ }^{23,24}$ affords the 4-arylated pyridine 13 in $80 \%$ yield (Scheme 2 ). ${ }^{25}$ The trifluoroacetamido group of $\mathbf{1 1}$ is an excellent directing group. Similarly, a sulfoxide function directs a magnesiation in the orthoposition with high efficiency. Thus, pyridine 14, bearing a sulfoxide function at position $\mathrm{C}$, is magnesiated at $-30^{\circ} \mathrm{C}$

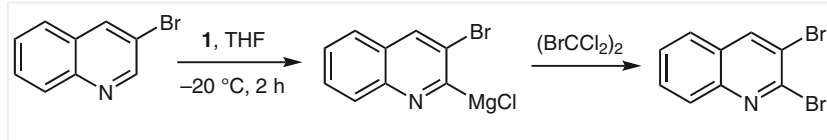

2

3

4: $65 \%$
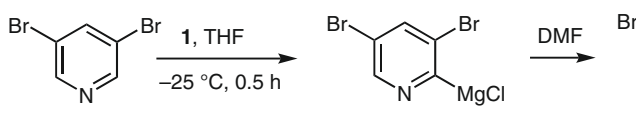

7<smiles>Cc1cnc(C=O)c(Br)c1</smiles>

5<smiles>COc1ccc(C(O)c2cc(Cl)nc(Cl)c2)cc1</smiles>

6

8

10: $92 \%$

Scheme 1 Regioselective magnesiation of halogenoazines using TMP$\mathrm{MgCl} \cdot \mathrm{LiCl}$ (1)

with TMPMgCl.LiCl (1) within 20 min (Scheme 3). Addition of $\mathrm{ZnCl}_{2}$ and Negishi cross-coupling with $p$-iodoanisole catalyzed by $5 \% \operatorname{Pd}\left(\mathrm{PPh}_{3}\right)_{4}\left(50{ }^{\circ} \mathrm{C}, 2 \mathrm{~h}\right)$ furnishes the tetrasubstituted pyridine $\mathbf{1 5}$ in $68 \%$ yield. The sulfoxide group can then be converted into a new magnesium reagent through sulfoxide-magnesium exchange ${ }^{26}$ in 2-methyl$\mathrm{THF}^{27}$ triggered by $i$-PrMgCl.LiCl $\left(-50{ }^{\circ} \mathrm{C}, 5 \mathrm{~min}\right)$. Transmetalation with $\mathrm{ZnCl}_{2}$ followed by a Negishi cross-coupling

\section{Biographical Sketches}
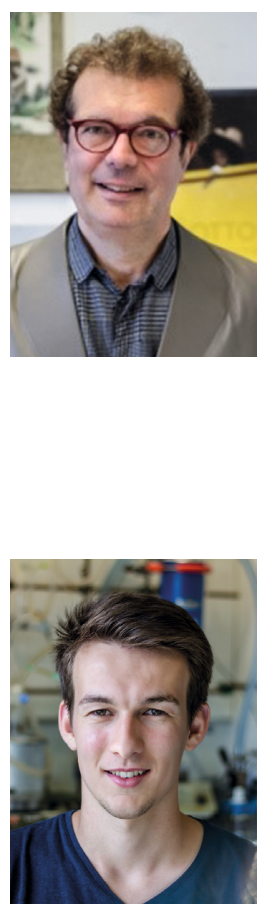

Paul Knochel was born in 1955 in Strasbourg (France). He studied at the University of Strasbourg (France) and did his Ph.D at the ETH-Zürich (D. Seebach). He spent four years at the University Pierre and Marie Curie in Paris (J.-F. Normant) and one year at Princeton University (M. F. Semmelhack). In 1987, he was Professor at the University of Michigan. In 1992, he moved to Philipps-University

Moritz Balkenhohl was born in 1992 in Speyer (Germany). He studied chemistry at the Julius-Maximilians-Universität Würzburg and at Imperial Col- at Marburg (Germany). In 1999, he then moved to the Chemistry Department of LudwigMaximilians-University in Munich (Germany). His research interests include the development of novel organometallic reagents and methods for use in organic synthesis, asymmetric catalysis and natural product synthesis. Prof. Knochel has received many distinguished prizes including the Berthelot Medal of the

lege London. In 2015 he joined the group of Prof. Paul Knochel for his Master thesis in Munich and started his PhD thesis in 2016. His research focuses on
Academie des Sciences (Paris), the IUPAC Thieme Prize, the Otto-Bayer-Prize, the LeibnizPrize, the Arthur C. Cope Scholar Award, Karl-Ziegler-Prize, the Nagoya Gold Medal, the H. C. Brown Award and Paul Karrer gold medal. He is member of the Académie des Sciences, the Bavarian Academy of Science, the German Academy of Sciences Leopodina. He is author of over 900 publications.

the functionalization of challenging heterocycles and transition-metal-free amination reactions. 
with ethyl 5-bromonicotinate (16), catalyzed by $2 \%$ $\mathrm{Pd}\left(\mathrm{PPh}_{3}\right)_{4}\left(50{ }^{\circ} \mathrm{C}, 5 \mathrm{~h}\right)$, leads to the complex bis-pyridine 17 in $82 \%$ yield (Scheme 3 ). ${ }^{28}$

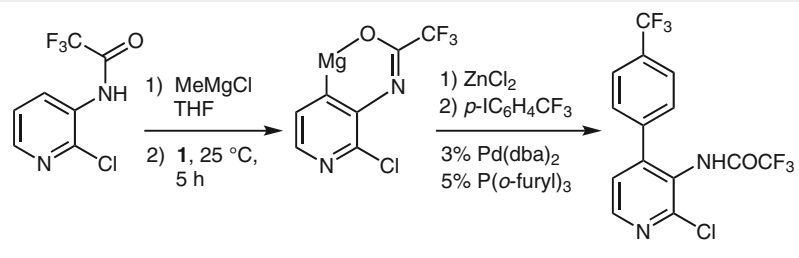

11

12

13: $80 \%$

Scheme 2 Magnesiation of a trifluoroamidopyridine using TMPMgCl.LiCl (1)

Likewise, sulfonamides are excellent directing groups ${ }^{2 \mathrm{c}-\mathrm{d}, 29}$ and can undergo amination reactions when treated with an excess of a magnesium amide. Thus, sulfonamides $\mathbf{1 8}$ and 19 are magnesiated with TMPMgCl$\cdot \mathrm{LiCl}\left(\mathbf{1} ; \mathrm{THF}, 0{ }^{\circ} \mathrm{C}, 2 \mathrm{~h}\right)$. After iodolysis and amination at $25^{\circ} \mathrm{C}(2 \mathrm{~h})$ with piperidylmagnesium chloride, aminoquinolines $\mathbf{2 0}$ and $\mathbf{2 1}$ are obtained in 52-59\% yield over two steps (Scheme 4). ${ }^{30}$

$\mathrm{TMPMgCl} \cdot \mathrm{LiCl}(\mathbf{1})$ also proves to be an excellent base for the $\mathrm{C}-\mathrm{H}$ activation of 3-methoxypyridine (22). Thus, treatment of 22 with $10 \% \mathrm{FeCl}_{3}$ and $25 \%$ diamine (23) and an excess of TMPMgCl$\cdot \mathrm{LiCl}(\mathbf{1})$ at $25^{\circ} \mathrm{C}$ for $2 \mathrm{~h}$ allows facile alkylation with various alkyl bromides such as 5-bromopentene (24), providing the alkylated product $\mathbf{2 5}$ in $85 \%$ yield (Scheme 5). ${ }^{31}$

The $N, N, N^{\prime}, N^{\prime}$-tetramethylphosphordiamidate group $\left(\mathrm{OP}(\mathrm{O})\left(\mathrm{NMe}_{2}\right)_{2}\right)$ was found to be a more powerful directing group than the methoxy group, ${ }^{32}$ which allows efficient magnesiations with TMPMgCl.LiCl (1). Thus, the 4-substituted pyridine 26 is magnesiated with 1 (1.5 equiv, $0{ }^{\circ} \mathrm{C}$, $1 \mathrm{~h}$ ) and subsequently thiolated by reaction with MeS$\mathrm{SO}_{2} \mathrm{Me}$, affording the disubstituted pyridine $\mathbf{2 7}$ in $88 \%$ yield.

Similarly, quinoline $\mathbf{2 8}$ was magnesiated with TMPMg$\mathrm{Cl} \cdot \mathrm{LiCl}(\mathbf{1})$ at $0{ }^{\circ} \mathrm{C}$ within $1 \mathrm{~h}$ and acylated in the presence of a copper(I)-catalyst (CuCN.2LiCl), furnishing the ketone $\mathbf{2 9}$ in $62 \%$ yield (Scheme 6 ). ${ }^{33}$ This method has been used to prepare the pyridine based COX-2 inhibitor etoricoxib $\mathbf{3 0}^{34}$ starting from the phosphordiamidate substituted pyridine 31. Thus, the magnesiation of $\mathbf{3 1}$ with $\mathrm{TMPMgCl} \cdot \mathrm{LiCl}(\mathbf{1})$ in THF at $0{ }^{\circ} \mathrm{C}$ for $1 \mathrm{~h}$, followed by a transmetalation with $\mathrm{ZnCl}_{2}$ and Negishi cross-coupling with aryl bromide 32 using 1\%<smiles>O=S(=O)(c1ccc2ccccc2n1)N1CCCCC1</smiles>

18

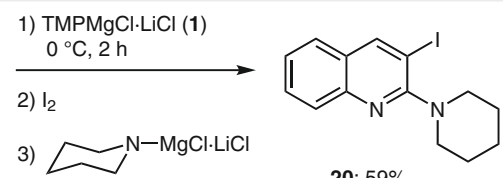

$25^{\circ} \mathrm{C}, 2 \mathrm{~h}$<smiles>O=S(=O)(c1cccc2cccnc12)N1CCCCC1</smiles>
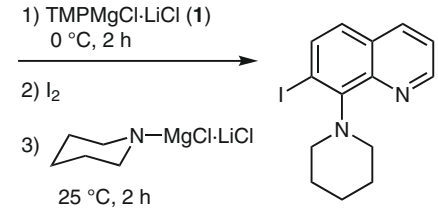

19

Scheme 4 ortho-Metalation, functionalization and amination of quinoline-sulfonamides

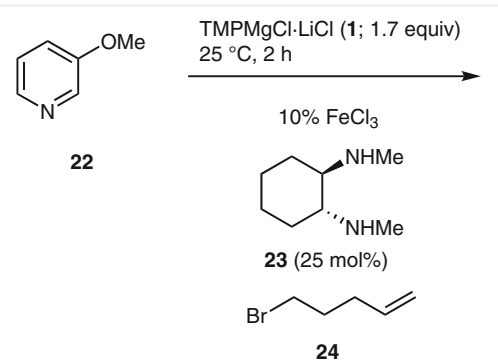

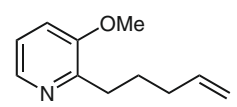

25: $85 \%$

Scheme 5 Iron-catalyzed alkylation of 3-methoxypyridine (22)<smiles>COc1ccncc1</smiles><smiles>COc1ccnc2ccccc12</smiles>

28
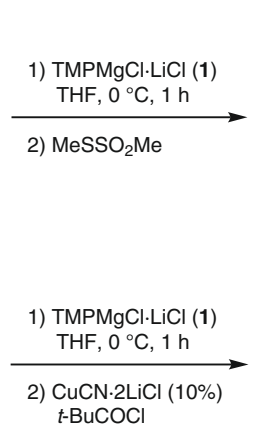
$t$-BuCOCl<smiles>COc1ccncc1OC</smiles>

27: $88 \%$<smiles>COc1cnc2ccccc2c1OC(C)([O-])O[Na]</smiles>

29: $62 \%$

Scheme 6 ortho-Magnesiation of a phosphordiamidate substituted pyridine and quinoline using TMPMgCl. LiCl (1)<smiles>COc1ccc(S(=O)c2cc(Cl)nc(Cl)c2)cc1</smiles>

14

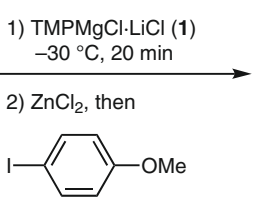

$5 \% \mathrm{Pd}\left(\mathrm{PPh}_{3}\right)_{4}$<smiles>COc1ccc(-c2c(S(=O)c3ccc(OC)cc3)cc(Cl)nc2Cl)cc1</smiles>

15: $68 \%$

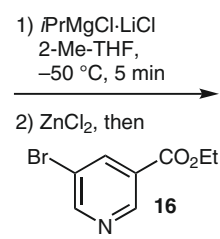

$2 \% \operatorname{Pd}\left(\mathrm{PPh}_{3}\right)_{4}$ $50^{\circ} \mathrm{C}, 5 \mathrm{~h}$<smiles>CCOC(=O)c1cncc(-c2cc(Cl)nc(Cl)c2-c2ccc(OC)cc2)c1</smiles>

17: $82 \%$

Scheme 3 ortho-Magnesiation of a pyridyl sulfoxide, followed by a sulfoxide-magnesium exchange 


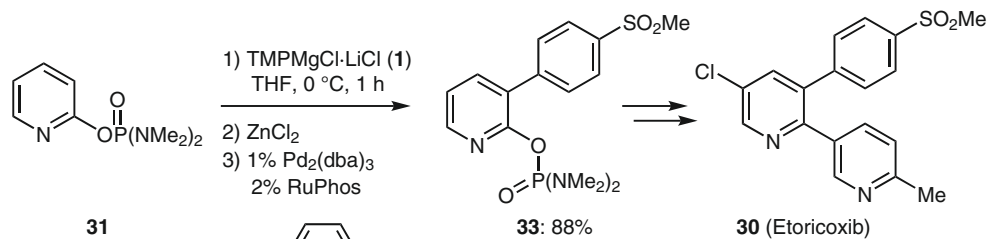

31

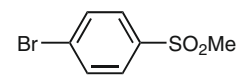

33: $88 \%$

30 (Etoricoxib)

32

Scheme 7 Synthesis of Etoricoxib (30) using TMPMgCl.LiCl (1)

$\mathrm{Pd}_{2}(\mathrm{dba})_{3}(\mathrm{dba}=$ dibenzylideneacetone $)$ and $2 \%$ RuPhos $^{35}$ provides the arylated pyridine 33 in $88 \%$ yield. Standard transformations and Stille cross-coupling ${ }^{36}$ provides the desired pharmaceutical $\mathbf{3 0}$ (Scheme 7). ${ }^{33}$

\subsection{Magnesiations using $\mathrm{TMP}_{2} \mathrm{Mg} \cdot 2 \mathrm{LiCl}(34)$ and Related Bases}

Although TMPMgCl.LiCl (1) is a very powerful magnesiation reagent, in the case of substrates bearing weakly acidic or sterically hindered protons, the magnesiation is advantageously performed using $\mathrm{TMP}_{2} \mathrm{Mg} \cdot 2 \mathrm{LiCl}(\mathbf{3 4}) \cdot{ }^{37}$ Often, the presence of sensitive functional groups, such as a carboethoxy group, requires low magnesiation temperatures, since higher temperatures lead to considerable side reactions. $\mathrm{TMP}_{2} \mathrm{Mg} \cdot 2 \mathrm{LiCl}$ (34), which is prepared in quantitative yield by treating TMPLi with 1 , can be stored at $25^{\circ} \mathrm{C}$ for several hours. A degradation after several days is however observed. This base readily magnesiates 4-carbethoxypyri- dine (35) at $-40{ }^{\circ} \mathrm{C}$ for $12 \mathrm{~h}$, leading to $\mathbf{3 6}$, furnishing, after iodolysis, the iodopyridine 37 in $66 \%$ yield (Scheme 8). ${ }^{37}$ The phosphordiamidate substituted quinoline $\mathbf{3 8}$ was magnesiated with 34, yielding the magnesium reagent 39 $\left(-50{ }^{\circ} \mathrm{C}, 1 \mathrm{~h}\right)$. After transmetalation with $\mathrm{ZnCl}_{2}$ and Negishi cross-coupling using $\mathrm{PhI}, 5 \% \mathrm{Pd}(\mathrm{dba})_{2}$ and $10 \% \mathrm{P}(0 \text {-furyl })_{3}$ as catalyst, $^{38}$ the arylated quinoline $\mathbf{4 0}$ is obtained in $81 \%$ yield. Interestingly, the quinoline $\mathbf{4 0}$ can now be magnesiated with $\mathrm{TMPMgCl} \cdot \mathrm{LiCl}(\mathbf{1})$ at $25^{\circ} \mathrm{C}$ within $1 \mathrm{~h}$. The presence of the phenyl group at position 2 avoids nucleophilic additions to the quinoline ring and allows higher metalation temperatures $\left(25^{\circ} \mathrm{C}\right.$ instead of $\left.-50{ }^{\circ} \mathrm{C}\right)$. Quenching with $\mathrm{NC}-\mathrm{CO}_{2}$ Et produces the 2,3,4-trisubstituted quinoline 41, which is further converted into Talnetant (42), an $\mathrm{NK}_{3}$ receptor antagonist, in $86 \%$ yield (Scheme 8 ). ${ }^{33}$

An alternative base with enhanced thermal stability derived from $t$-butyl-isopropylamine $(t \mathrm{Bu}(i \mathrm{Pr}) \mathrm{NH}, 43)$ was obtained by treating 43 with $n$-BuLi, giving 44 , followed by the addition of $t \mathrm{Bu}(i \mathrm{Pr}) \mathrm{NMgCl} \cdot \mathrm{LiCl}(\mathbf{4 5})$, affording the

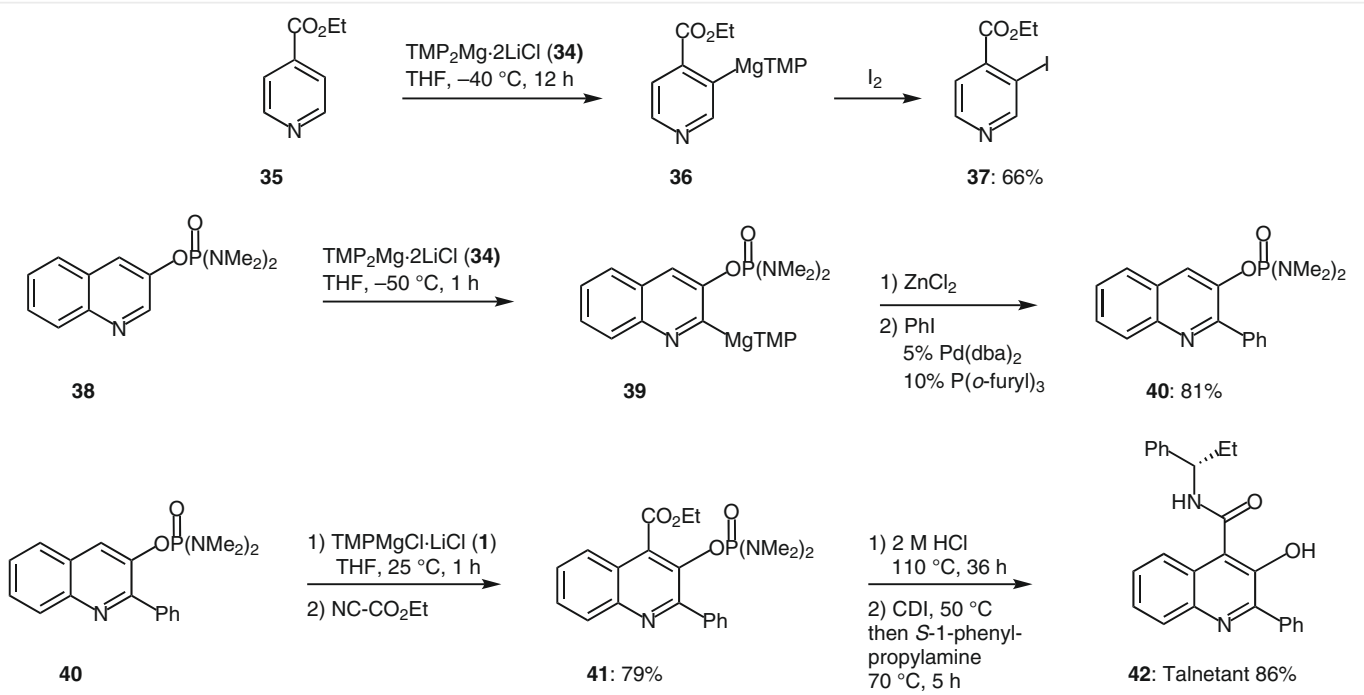

Scheme 8 Azine functionalization using $\mathrm{TMP}_{2} \mathrm{Mg} \cdot 2 \mathrm{LiCl}$ (34) 
magnesium bis-amide $\mathbf{4 6}$ in $>90 \%$ yield (Scheme 9). ${ }^{39}$ The metalation of 4-t-butoxycarbonylpyridine (47) with 46 provides the expected pyridine $\mathbf{4 8}$ in $68 \%$ yield (Scheme 9). ${ }^{39}$

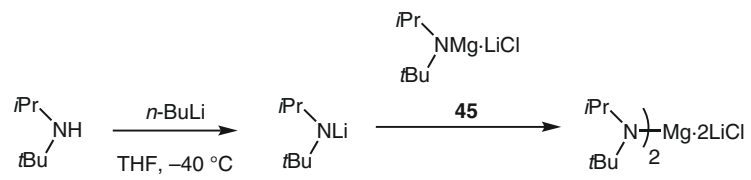

$$
\begin{aligned}
& 43 \quad 44 \\
& \text { 46: } 0.85 \mathrm{M} \text { in THF } \\
& { }_{\mathrm{tBu}}^{\mathrm{Pr}} \mathrm{N}_{2}^{\mathrm{N}} \mathrm{H}_{2} \mathrm{Mg} \cdot 2 \mathrm{LiCl}
\end{aligned}
$$

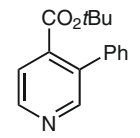

Scheme 9 Preparation of $\mathbf{4 6}$ and magnesiation of $\mathbf{4 7}$ with $[i \mathrm{Pr}(\mathrm{tBu}) \mathrm{N}]_{2} \mathrm{Mg} \cdot 2 \mathrm{LiCl}(\mathbf{4 6})$

\section{3 $\mathrm{BF}_{3} \cdot \mathrm{OEt}_{2}$-Promoted Metalations of Pyridines}

A typical mono-substituted pyridine, 3-fluoropyridine (49), can be metalated in two complementary positions (position C2 or position C4) with TMPMgCl.LiCl (1), either in the absence or in the presence of the strong Lewis acid $\mathrm{BF}_{3} \cdot \mathrm{OEt}_{2}$ (Scheme 10). Preliminary experiments showed that $\mathrm{BF}_{3} \cdot \mathrm{OEt}_{2}$ does not react in an irreversible manner with $\mathrm{TMPMgCl} \cdot \mathrm{LiCl}(\mathbf{1})$ at temperatures below $-30^{\circ} \mathrm{C}$. Also, the 3fluoro substituent considerably acidifies the adjacent positions $\mathrm{C} 2$ and $\mathrm{C} 4$ of $\mathbf{4 9}$. The position of the metalation is determined by the nature of the complexation with the TMPbase. ${ }^{40}$ Thus, by adding TMPMgCl.LiCl (1) to $\mathbf{4 9}$, a complexation of $\mathbf{1}$ to the heterocyclic $\mathrm{N}$-atom takes place, leading to a complex of type 50, which favors metalation at position $\mathrm{C} 2$. On the other hand, in the presence of $\mathrm{BF}_{3} \cdot \mathrm{OEt}_{2}$, this strong Lewis acid forms a complex with the $\mathrm{N}$-atom of the pyridine ring and the base $\mathbf{1}$ may, if at all, only complex the fluorine substituent.

This favors a metalation at position C4 (see 51). Thus, the presence or absence of $\mathrm{BF}_{3} \cdot \mathrm{OEt}_{2}$ allows the arylation of 3-fluoropyridine (49) either in position $\mathrm{C} 2$ or $\mathrm{C} 4$, leading to the expected products $\mathbf{5 2}$ and $\mathbf{5 3}$ (Scheme 10)..$^{40}$ The exact nature of the organometallic species obtained after the metalation of 49 in the presence of $\mathrm{BF}_{3} \cdot \mathrm{OEt}_{2}$ has been examined by ${ }^{13} \mathrm{C}$ NMR spectroscopy. ${ }^{40,41}$ This regioselectivity switch is observed for a range of pyridines. An unexpected regioselectivity is observed in the case of 2-phenylpyridine (54). Thus, the treatment of $\mathbf{5 4}$ with TMPMgCl-LiCl (1) at $55^{\circ} \mathrm{C}$ provides the magnesiated pyridine $\mathbf{5 5}$. After iodolysis, pyridine $\mathbf{5 6}$ is obtained in $\mathbf{8 5} \%$ yield. Alternatively, the treat-
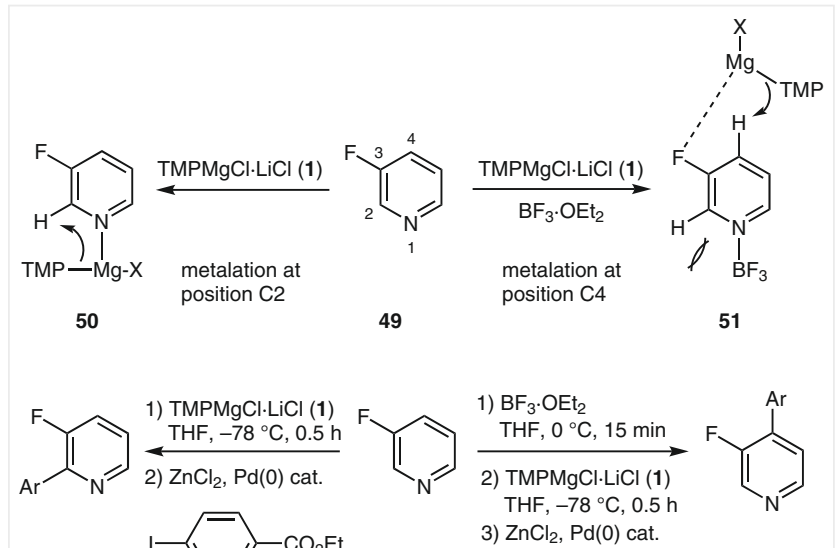

52: $72 \%$

49

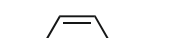

53: $74 \%$

Scheme 10 Regioselective metalation of 3-fluoropyridine $\mathbf{4 9}$ in the presence or absence of $\mathrm{BF}_{3} \cdot \mathrm{OEt}_{2}$

ment of $\mathbf{5 4}$ with $\mathrm{BF}_{3} \cdot \mathrm{OEt}_{2}$, followed by TMPMgCl$\cdot \mathrm{LiCl}(\mathbf{1})$, furnishes, after iodolysis, the 2,6-disubstituted pyridine $\mathbf{5 7}$ in $83 \%$ yield (Scheme 11 ). ${ }^{40}$

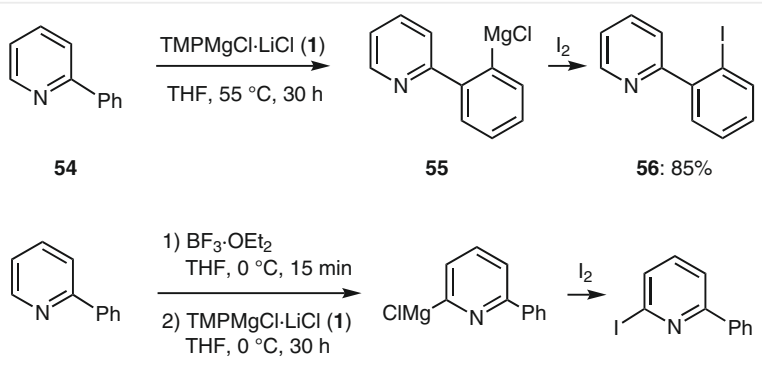

54

57: $83 \%$

Scheme 11 Regioselective metalation of 2-phenylpyridine (54) with or without $\mathrm{BF}_{3} \cdot \mathrm{OEt}_{2}$

This methodology also allows the functionalization of 4dimethylaminopyridine (58) in position 2 . In this case, the coordination with $\mathrm{BF}_{3} \cdot \mathrm{OEt}_{2}$ greatly acidifies all the heterocyclic hydrogen atoms, especially those in position C2. Thus, treatment of $\mathbf{5 8}$ with $\mathrm{BF}_{3} \cdot \mathrm{OEt}_{2}$ in THF, followed by $\mathrm{TMPMgCl} \cdot \mathrm{LiCl}(\mathbf{1})$ at $0{ }^{\circ} \mathrm{C}$ for $1 \mathrm{~h}$, furnishes the magnesium derivative $\mathbf{5 9}$ or, after metallotropy, the trifluoroborate derivative 60. After a copper(I)-catalyzed acylation, the 2ketopyridine 61 is obtained in $68 \%$ yield ${ }^{42}$ Similarly, 2chloro-4-dimethylaminopyridine $(\mathbf{6 2})$ is allylated via the organometallic intermediate $\mathbf{6 3}$, furnishing the trisubstituted pyridine $\mathbf{6 4}$ in $78 \%$ yield (Scheme 12 ). ${ }^{42}$ 


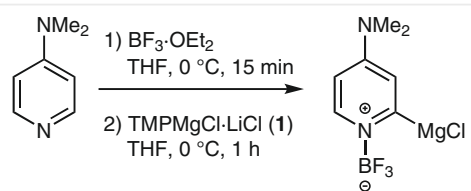

58

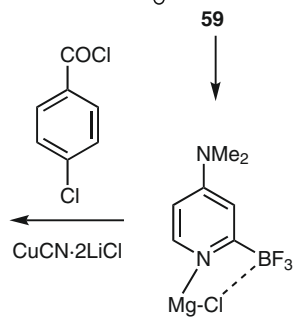

60

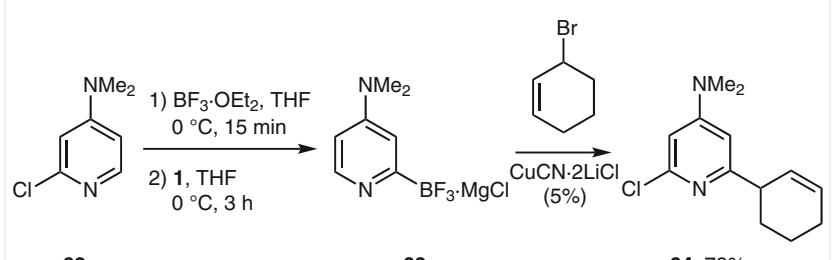

62

63

64: $78 \%$

Scheme 12 Functionalization of 4-dimethylaminopyridine (58) using $\mathrm{TMPMgCl} \cdot \mathrm{LiCl}(\mathbf{1})$ and $\mathrm{BF}_{3} \cdot \mathrm{OEt}_{2}$

Furthermore a regioselective functionalization of $(S)$ nicotine (65) via the organometallic intermediate $\mathbf{6 6}$, leading to 6 -functionalized nicotine derivatives, such as $\mathbf{6 7}$, is feasible. ${ }^{42}$ Similarly, the metalation of quinine $(\mathbf{6 8})$ can be tuned depending on the reaction conditions used. Thus, the formation of the lithium alcoholate of quinine followed by the addition of $\mathrm{BF}_{3} \cdot \mathrm{OEt}_{2}$ (2 equiv) is tentatively thought to provide intermediate $\mathbf{6 9}$, which leads to a complexation of $\mathbf{1}$ at the basic tertiary nitrogen atom and therefore leads to the 3-iodinated quinoline $\mathbf{7 0}$ in 65\% yield (Scheme 13). ${ }^{42}$

By tuning the protecting groups attached to quinine (68), a switch of the metalation is observed. Thus, the conversion of $\mathbf{6 8}$ into the TBDMS-silyl enol ether $\mathbf{7 1}$ followed by addition of $\mathrm{BF}_{3} \cdot \mathrm{OEt}_{2}$ (1 equiv) now leads to the $\mathrm{BF}_{3}$ adduct 72, which can be metalated with TMPMgCl.LiCl (1) exclusively at the position C2, providing, after iodolysis, the 2 -iodoquinine derivative $\mathbf{7 3}$ in $44 \%$ yield (Scheme 14). ${ }^{42}$

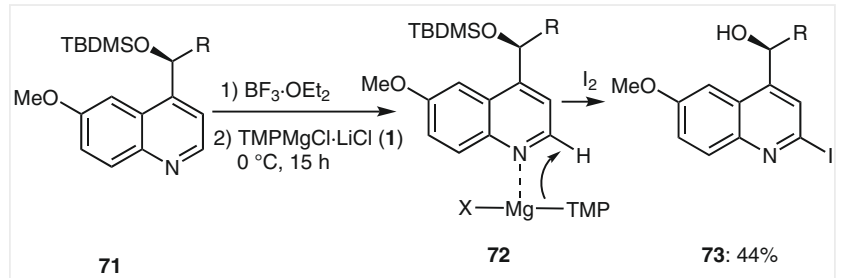

Scheme $14 \mathrm{BF}_{3} \cdot \mathrm{OEt}_{2}$-triggered metalation of a silyl-derivative of quinine (71)

The regioselectivity of the metalation of pyridines and quinolines is the result of steric and electronic factors, often leading to kinetically controlled products. Thus, the bistrimethylsilylmethyl group, which is readily attached to the pyridine scaffold, directs the metalation by steric effects. Therefore, the 3-substituted pyridine $\mathbf{7 4}$ was activated with $\mathrm{BF}_{3} \cdot \mathrm{OEt}_{2}\left(0^{\circ} \mathrm{C}, 15 \mathrm{~min}\right)$ and magnesiated with $\mathrm{TMP}_{2} \mathrm{Mg} \cdot 2 \mathrm{LiCl}$ (34), since the magnesiation with 1 proved to be ineffective. The $\mathrm{BF}_{3}$-adduct $\mathbf{7 5}$ is exclusively metalated at position $\mathrm{C} 6$, providing, after a Negishi cross-coupling with an iodopyrimidine, the bis-azine $\mathbf{7 6}$ in $65 \%$ yield (Scheme 15 ). ${ }^{43}$ Interestingly, 6-bromo-3-bis(trimethylsilylmethyl)pyridine (77) can be directly metalated by $\mathrm{TMP}_{2} \mathrm{Mg} \cdot 2 \mathrm{LiCl}(34)$ at $0{ }^{\circ} \mathrm{C}$ for $25 \mathrm{~h}$, affording the magnesium derivative 78 . Due to the steric hindrance of the silyl-substituent at position C3, no magnesiation occurs at position $\mathrm{C} 2$, and only a magnesiation is observed at position C5. Subsequent acylation with an acid chloride, after transmetalation to copper(I) with CuCN.2LiCl, provides ketone $\mathbf{7 9}$ in $60 \%$ yield (Scheme 15 ). ${ }^{43}$

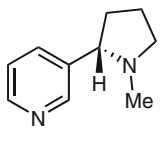

65: (S)-nicotine

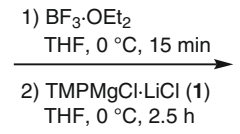

$\mathrm{HF}, 0^{\circ} \mathrm{C}, 2.5 \mathrm{~h}$<smiles></smiles>

66

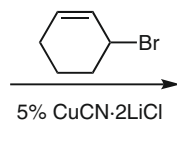

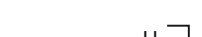<smiles>C=C[C@H]1CN2CC[C@@H]1[C@H]([C@H](O)c1ccnc3ccc(OC)cc13)[C@@H]2C</smiles>

68

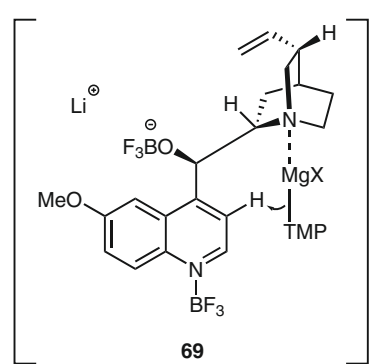

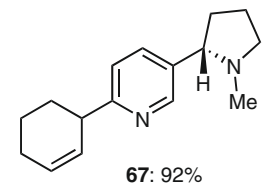

67: $92 \%$

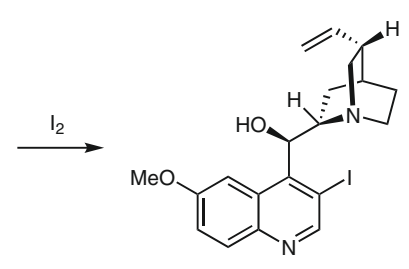

70: $65 \%$

Scheme $13 \mathrm{BF}_{3} \cdot \mathrm{OEt}_{2}$-triggered metalation of $(S)$-nicotine (65) and quinine (68) using TMPMgCl.LiCl (1) 
<smiles></smiles>

74

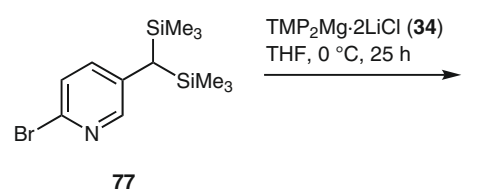<smiles></smiles>

75<smiles>COc1nc(Cl)cc(-c2ccc(C(C)C)cn2)n1</smiles>

76: $65 \%$<smiles>COc1cc(C(C)C)cnc1Br</smiles><smiles>CC(C)c1cnc(Br)c(C(=O)c2cccc(Cl)c2)c1</smiles>

Scheme 15 Metalation of sterically hindered pyridines bearing a bis-trimethylsilylmethyl substituent

\section{Zincation of Pyridines and Related Azines using $\mathrm{TMPZnCl} \cdot \mathrm{LiCl}$ and $\mathrm{TMP}_{2} \mathrm{Zn} \cdot \mathbf{2} \mathrm{LiCl} \cdot 2 \mathrm{MgCl}_{2}$}

The availability of kinetically active zinc amides further extends the scope of directed metalations of functionalized azines. Two complementary zinc bases TMPZnCl.LiCl (80) and $\mathrm{TMP}_{2} \mathrm{Zn} \cdot 2 \mathrm{LiCl} \cdot 2 \mathrm{MgCl}_{2}(\mathbf{8 1})$ are obtained from TMPLi and $\mathrm{ZnCl}_{2}$ or TMPMgCl.LiCl (1) and $\mathrm{ZnCl}_{2}$ (Scheme 16). ${ }^{11,44,45}$ Since the carbon-zinc bond is much more covalent than the carbon-magnesium bond, electrophilic functional groups are much better tolerated in such zinc organometallics and the directed zincation of various functionalized pyridines such as $\mathbf{8 2}$ and $\mathbf{8 3}$ is readily achieved. ${ }^{14}$ As the carbon-zinc bond in heteroarylzinc reagents is stable up to $100^{\circ} \mathrm{C}$, directed zincations of pyridines $\mathbf{8 2 - 8 3}$ have been performed under microwave irradiation under elevated temperatures $\left(60-80^{\circ} \mathrm{C}\right)$, providing the corresponding dipyridylzinc reagents 84-85 in high yields. After quenching with electrophiles such as allylic bromides or acyl chlorides in the presence of a copper(I) catalyst, the expected products 86-87 are obtained in $68-80 \%$ yield (Scheme 16 ). ${ }^{14}$

Furthermore, pyridylzinc organometallics do not undergo electron-transfer reactions. Therefore, the electron-deficient nitro group is well tolerated in the zincation of nitrosubstituted pyridines such as $\mathbf{8 8}$. In this case, the zincation proceeds at $-40{ }^{\circ} \mathrm{C}$ within $1.5 \mathrm{~h}$, leading to the bis-pyridylzinc 89. After a copper-catalyzed allylation with 3-bromocyclohexene, the trisubstituted pyridine $\mathbf{9 0}$ is obtained in $\mathbf{8 0 \%}$ yield (Scheme 17). ${ }^{44}$ Alternatively, the milder zinc base TMPZnCl. $\mathrm{LiCl}(\mathbf{8 0})$ can be used to zincate 88 at $25^{\circ} \mathrm{C}$ within $5 \mathrm{~h}$ and does not require low temperature metalations ${ }^{45,46}$ leading to the acylated pyridine $\mathbf{9 1}$ in $77 \%$ yield on $50 \mathrm{mmol}$ scale (Scheme 17). ${ }^{46}$

Highly oxidized pyridines, such as pyridine $\mathrm{N}$-oxides, are smoothly zincated with TMPZnCl.LiCl $(\mathbf{8 0})$ at $25^{\circ} \mathrm{C}$ and such functionalizations of pyridines are possible in large scale $(20 \mathrm{mmol})$ in high yields.

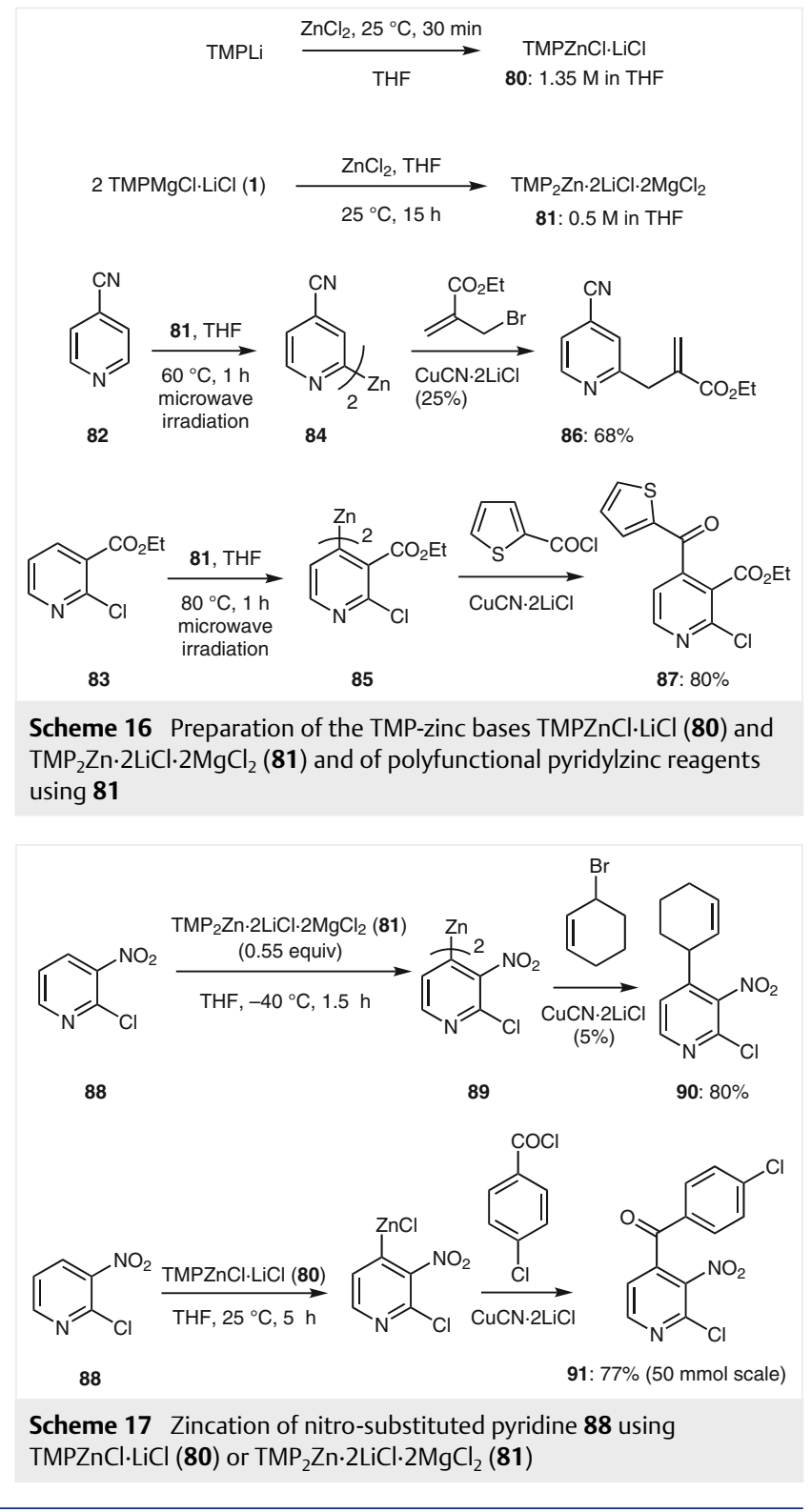


Thus, a room-temperature zincation of pyridine $\mathrm{N}$-oxide 92 with TMPZnCl-LiCl (80), and subsequent cross-coupling with the heteroaryl bromide $\mathbf{9 3}$, provides the desired crosscoupling product 94 in 95\% yield. Remarkably, this reaction has been extended to diazine $\mathrm{N}$-oxides such as pyridazine $\mathrm{N}$-oxide 95, providing, after cross-coupling with the heterocyclic bromide 96, the complex heterocycle $\mathbf{9 7}$ in $66 \%$ yield (Scheme 18). ${ }^{47}$<smiles>COc1c(Cl)cc[n+]([O-])c1C</smiles>

92<smiles>[O-][n+]1ccccn1</smiles>

95

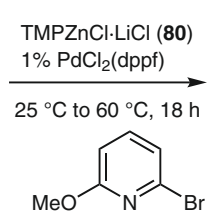

93

TMPZnCI.LiCl (80) $\underset{25{ }^{\circ} \mathrm{C} \text { to } 60^{\circ} \mathrm{C}, 18 \mathrm{~h}}{\stackrel{1 \% \mathrm{PdCl}_{2}(\mathrm{dppf})}{\longrightarrow}}$ $25^{\circ} \mathrm{C}$ to $60^{\circ} \mathrm{C}, 18$<smiles>Brc1ncnn2cccc12</smiles>

96<smiles>COc1cccc(-c2cc(Cl)c(OC)c(C)[n+]2[O-])n1</smiles>

94: $95 \%$ (20 mmol scale)<smiles>[O-][n+]1ncccc1-c1ncnn2cccc12</smiles>

97: $66 \%$
Scheme 18 Metalation of azine $\mathrm{N}$-oxides using TMPZnCl.LiCl (80)

The use of TMPZnCl. $\mathrm{LiCl}(\mathbf{8 0})$ is compatible with electrophilic aminations as shown by Wang. ${ }^{48,49}$ Thus, TMPZnCl.LiCl (80) regioselectively zincates 3 -fluoropyridine $(49)$ at $25^{\circ} \mathrm{C}$. Addition of a $\mathrm{Cu}(\mathrm{II})$-catalyst $\left(5 \mathrm{~mol} \% \mathrm{Cu}(\mathrm{OAc})_{2}\right.$ ) at $50{ }^{\circ} \mathrm{C}$ for $18 \mathrm{~h}$ in the presence of the electrophilic amination reagent, a benzoyloxypiperazine derivative $(\mathbf{9 8})$, provides the amination product 99 in $53 \%$ yield at a $60 \mathrm{mmol}$ scale. A related cobalt(II)-catalyzed amination can be performed under milder conditions using $\mathrm{CoCl}_{2} \cdot 2 \mathrm{LiCl}$ as catalyst (2.5\%). In this case, the amination proceeds at $25{ }^{\circ} \mathrm{C}$. Thus, pyridylzinc pivalate 100 and $101,{ }^{50}$ obtained by the magnesiation of the corresponding azine and diazine 102 and 103 with TMPMg$\mathrm{Cl} \cdot \mathrm{LiCl}(\mathbf{1})$ followed by the addition of $\mathrm{Zn}(\mathrm{OPiv})_{2}$, are treated with $\mathrm{N}$-hydroxymorpholine benzoate in THF at $25^{\circ} \mathrm{C}$ for 2 $\mathrm{h}$, furnishing the aminated derivatives 104 and 105 in 9195\% yield (Scheme 19). ${ }^{51}$

The performance of lateral zincations of pyridines has been achieved by using $\mathrm{TMP}_{2} \mathrm{Zn} \cdot 2 \mathrm{LiCl} \cdot 2 \mathrm{MgCl}_{2}$ (81). Thus, the treatment of the cyanohydrine derivative 106 with $\mathrm{TMP}_{2} \mathrm{Zn} \cdot 2 \mathrm{LiCl} \cdot 2 \mathrm{MgCl}_{2}(\mathbf{8 1})$ at $0{ }^{\circ} \mathrm{C}$ for $1 \mathrm{~h}$ provides the benzylic pyridylzinc derivative 107.

This zinc reagent can be acylated with cyclopropanecarbonyl chloride in the presence of $20 \% \mathrm{CuCN} \cdot 2 \mathrm{LiCl}$, affording, after tetrabutylammonium fluoride (TBAF) treatment, ketone $\mathbf{1 0 8}$ in $80 \%$ yield (Scheme 20). ${ }^{52}$

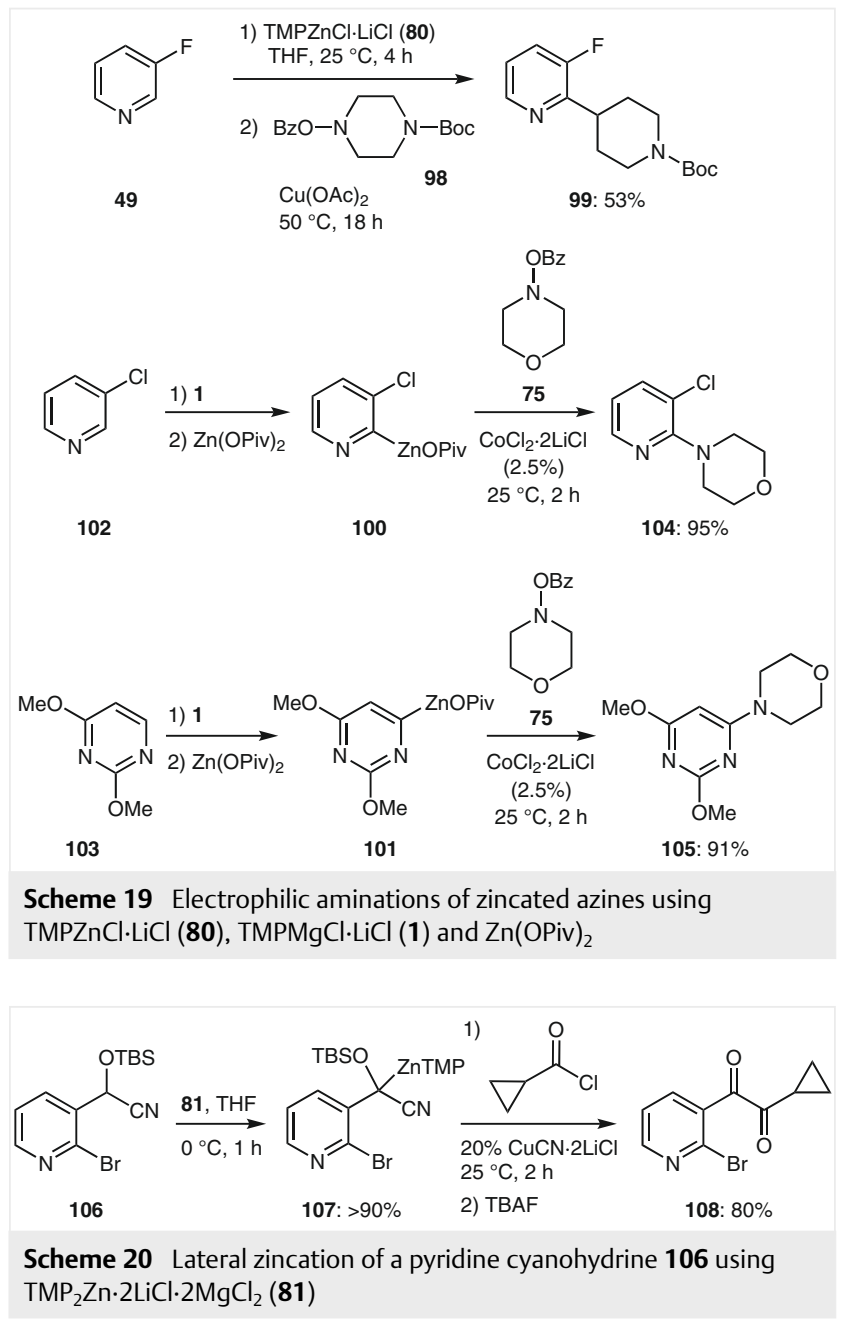

The scope of azine zincations has been extended by performing a Barbier type zincation in which the metalation is performed with TMPLi in the presence of $\mathrm{ZnCl}_{2} \cdot 2 \mathrm{LiCl}$ at low temperature. Thus, to a mixture of $\mathrm{ZnCl}_{2} \cdot 2 \mathrm{LiCl}$ and the substrate pyridine 109, a THF solution of TMPLi (ca. 1.5 equiv) is added at $-78{ }^{\circ} \mathrm{C}$. Under these conditions, the directed lithiation of $\mathbf{1 0 9}$ is fast, producing the ortho-lithiated pyridine 110, which is a highly reactive intermediate, that is transmetalated in situ with the soluble $\mathrm{ZnCl}_{2} \cdot 2 \mathrm{LiCl}$, providing the stable pyridylzinc reagent 111. Quenching with an electrophile (E-X) under appropriate reaction conditions furnishes then the functionalized pyridine 112 (Scheme $21)^{53}$ 

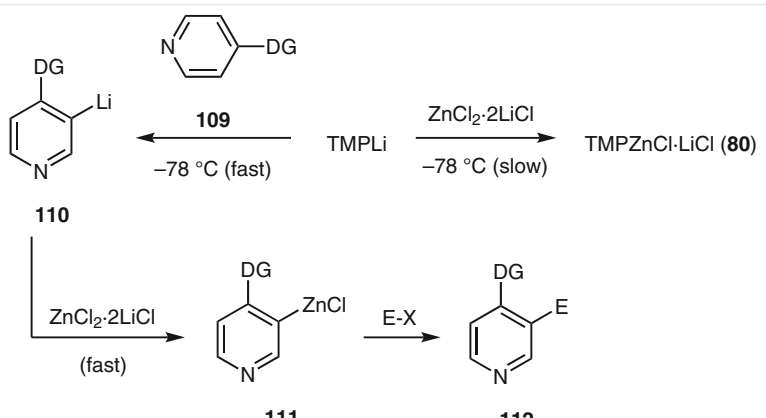

$111 \quad 112$

Scheme 21 Barbier type metalation of pyridine 81 using TMPLi in the presence of $\mathrm{ZnCl}_{2} \cdot 2 \mathrm{LiCl}$

That such a Barbier reaction proceeds properly relies on the slow transmetalation between TMPLi and $\mathrm{ZnCl}_{2} \cdot 2 \mathrm{LiCl}$ at $-78{ }^{\circ} \mathrm{C}$. On the other hand, the directed lithiation and transmetalation steps are required to be fast. ${ }^{53}$ This reaction setup has a good reaction scope and the functionalized pyridines 113-115 are smoothly metalated under these in situ trapping conditions, using either $\mathrm{ZnCl}_{2} \cdot 2 \mathrm{LiCl}$ or $\mathrm{MgCl}_{2} \cdot 2 \mathrm{LiCl}$ as trapping salts, providing the zincated pyridine derivatives 116-118. After quenching with various electrophiles (aldehydes or aryl halides in the presence of a Pd-catalyst) the polyfunctionalized pyridines 119-121 are obtained in 79-94\% yield (Scheme 22). ${ }^{53}$

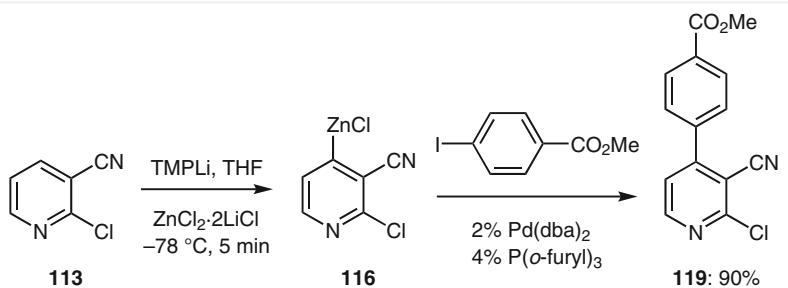

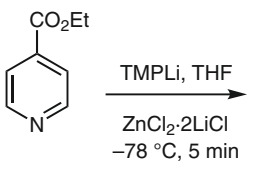

114

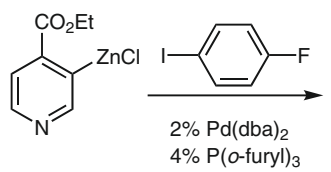

117<smiles>CCOC(=O)c1ccncc1-c1ccc(F)cc1</smiles>

120: $79 \%$
115

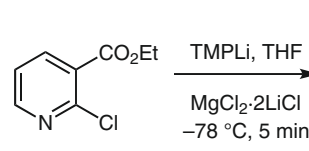

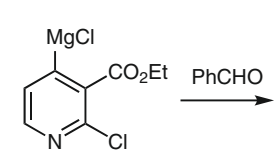

118<smiles>O=C1OC(c2ccccc2)c2ccnc(Cl)c21</smiles>

121: $94 \%$
Scheme 22 In situ trapping metalations of polyfunctional pyridines 113-115

The drawback of these metalations are the required low reaction temperatures. This problem was overcome by using a continuous-flow setup (Scheme 23). ${ }^{\text {a }}$ Thus, pyridine substrates bearing a directing group (DG) are mixed with a metallic salt $\left(\mathrm{ZnCl}_{2} \cdot 2 \mathrm{LiCl} ; \mathrm{MgCl}_{2} \cdot 2 \mathrm{LiCl}\right.$ or $\left.\mathrm{CuCN} \cdot 2 \mathrm{LiCl}\right)$, and added to a TMPLi solution in THF. These solutions were combined in a commercial flow setup from Uniqsis (1.80 $\mathrm{mL} / \mathrm{min}$ ) at $0{ }^{\circ} \mathrm{C}$ for $40 \mathrm{~s}$. This continuous-flow setup has several advantages, such as enabling a reaction temperature of $0{ }^{\circ} \mathrm{C}$ and a short reaction time of $40 \mathrm{~s}$. Also, the reaction can be readily scaled-up by pumping the solutions longer (Scheme 23). ${ }^{7 \mathrm{a}}$

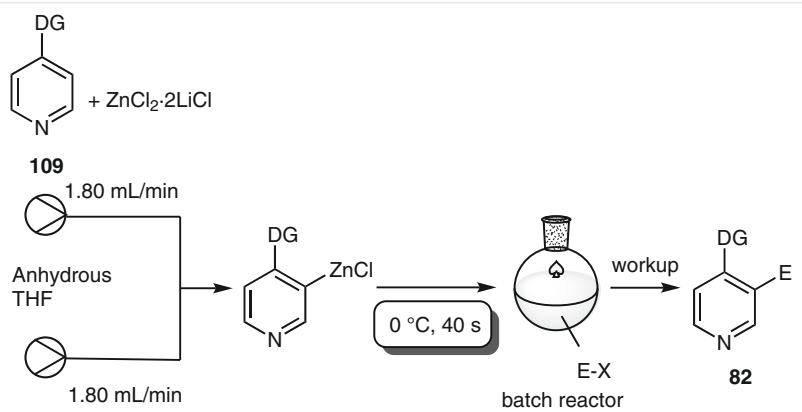

TMPLi (1.5 equiv)

Scheme 23 Continuous-flow setup for in situ trapping metalations

By using this procedure, a range of pyridines such as 122-123 are readily functionalized via the intermediate organometallics 124-125 leading to the expected products 126-127 in 80-98\% yield (Scheme 24). ${ }^{7 \mathrm{a}}$<smiles>Fc1ncccc1-c1ccc(C(F)(F)F)cc1</smiles>
122 124 126: $98 \%$<smiles>N#Cc1ncc(C2CCCCC2)cc1Cl</smiles>
123 125 127: $80 \%$

Scheme 24 Continuous-flow metalation of pyridines 122-123 using TMPLi in the presence of a metallic salt

In some cases, this procedure may be performed by replacing TMPLi with the 100 times cheaper lithium biscyclohexylamide $\left(\mathrm{Cy}_{2} \mathrm{NLi}\right) .{ }^{54}$ For example, the ethyl nicotinate 115 was metalated with $\mathrm{Cy}_{2} \mathrm{NLi}$ (1.5 equiv) at $0{ }^{\circ} \mathrm{C}$ within $40 \mathrm{~s}$ and further allylated under copper(I)-catalysis in batch, leading to the pyridine $\mathbf{1 2 8}$ in $88 \%$ yield (Scheme 25). ${ }^{54}$ 


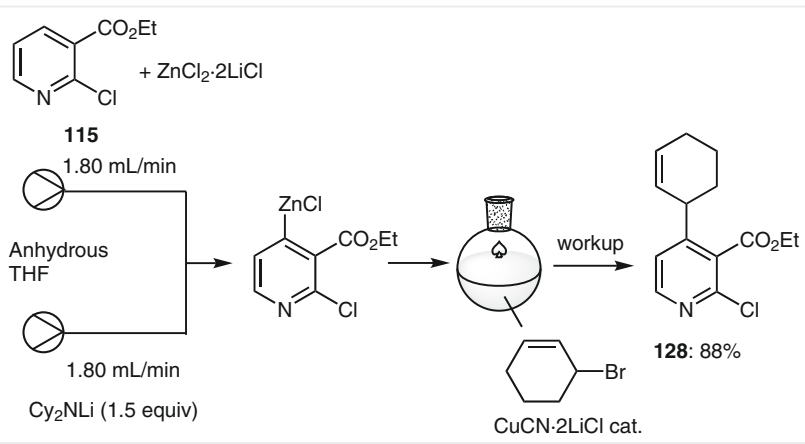

Scheme $\mathbf{2 5}$ Continuous-flow metalation of pyridine $\mathbf{1 1 5}$ in the presence of $\mathrm{ZnCl}_{2} \cdot 2 \mathrm{LiCl}$ using $\mathrm{Cy}_{2} \mathrm{NLi}$ as a cheap lithium amide

The combined use of TMP-zinc and magnesium bases (TMPMgCl.LiCl (1), TMPZnCl.LiCl (80) and $\mathrm{TMP}_{2} \mathrm{Zn} \cdot 2 \mathrm{LiCl} \cdot$ $2 \mathrm{MgCl}_{2}(\mathbf{8 1})$ ) in several cases allows a full functionalization of the pyridine scaffold. Thus, the treatment of 5-bromo-2chloropyridine (129) with TMPMgCl. $\mathrm{LiCl}(\mathbf{1})$ in THF $\left(-40{ }^{\circ} \mathrm{C}\right.$, $3 \mathrm{~h}$ ), followed by the addition of tosyl cyanide furnishes the regioselective product 130 in $68 \%$ yield. ${ }^{42}$ Remarkably, the pyridine 130 is magnesiated at low temperature with TMP$\mathrm{MgCl} \cdot \mathrm{LiCl}$ (1), affording the 4-magnesiated pyridine 131. The regioselectivity of this magnesiation may be explained by a preferential complexation of TMPMgCl$\cdot \mathrm{LiCl}(\mathbf{1})$ to the bromo-substituent, triggering a metalation in position $\mathrm{C} 4$. Quenching with $\mathrm{MeSO}_{2} \mathrm{SMe}$ provides thioether 132 in $81 \%$ yield. The last metalation is best performed with $\mathrm{TMP}_{2} \mathrm{Zn} \cdot 2 \mathrm{LiCl} \cdot 2 \mathrm{MgCl}_{2}$ (81), leading to the bis-pyridylzinc 133, which was transmetalated to the copper derivative with $\mathrm{CuCN} \cdot 2 \mathrm{LiCl}$ and benzoylated with $\mathrm{PhCOCl}$, leading to the pentasubstituted pyridine 134 in 61\% yield (Scheme 26). ${ }^{42}$

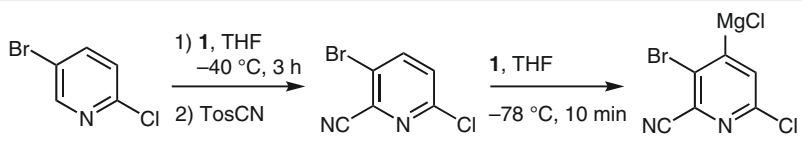

129 130: $68 \%$ 131: $>90 \%$ $\mathrm{MeSO}_{2} \mathrm{SMe} \downarrow$<smiles>COc1cc(Cl)nc(C#N)c1Br</smiles>
134: $61 \%$ 133 132: $81 \%$

Scheme 26 Full functionalization of the pyridine scaffold

\section{Metalation of Pyridines using other TMP- Bases}

It should be mentioned that related TMP-amide base derivatives from manganese, ${ }^{55}$ aluminum, ${ }^{56}$ and lanthanum ${ }^{57}$ have been reported. Thus, 2-chloro-5-fluoropyridine 135 can be treated with $\mathrm{TMP}_{2} \mathrm{Mn} \cdot 4 \mathrm{LiCl}_{2}\left(\mathrm{THF}, 0^{\circ} \mathrm{C}, 4 \mathrm{~h}\right)$, leading to the bis-pyridylmanganese species 136. After the addition of chloranil ( 1 equiv) at $-40{ }^{\circ} \mathrm{C}$ for $0.5 \mathrm{~h}$, the bis-pyridine 137 is obtained in $64 \%$ yield. ${ }^{55}$ The reaction of the 3 -cyanopyridine 113 with $\mathrm{TMP}_{2} \mathrm{Mn} \cdot 4 \mathrm{LiCl}\left(\mathrm{THF}, 0{ }^{\circ} \mathrm{C}, 0.5 \mathrm{~h}\right.$ ) affords an intermediate manganese-species 138, which, after transmetalation with $\mathrm{CuCl} \cdot 2 \mathrm{LiCl}$, followed by the addition of $\mathrm{LiN}\left(\mathrm{SiMe}_{3}\right)_{2}$, leads to 139 and oxidative amination with chloranil gives the 4-aminopyridine 140 in 75\% yield (Scheme 27). ${ }^{55 a}$

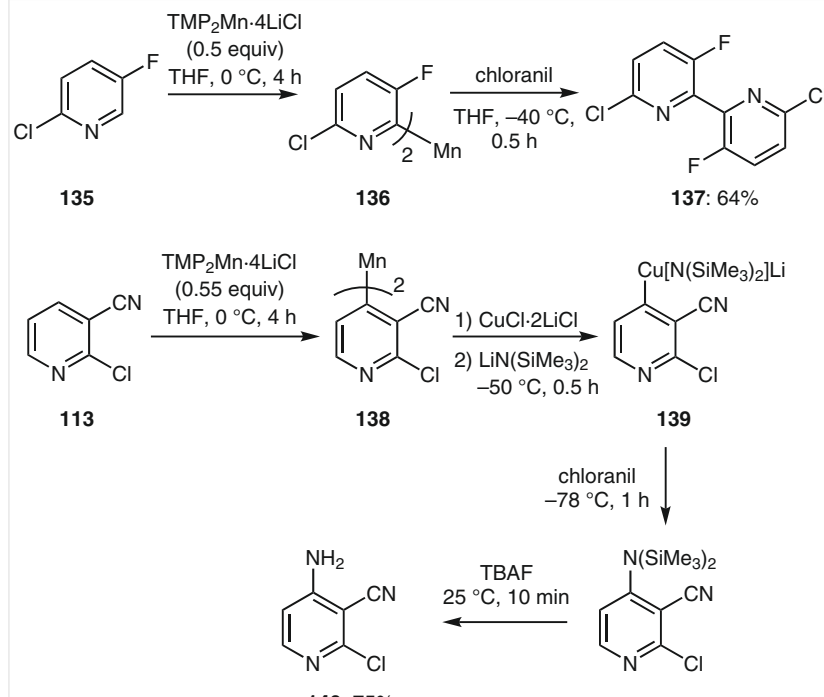

140: $75 \%$

Scheme 27 Magnesiation of pyridine derivatives using $\mathrm{TMP}_{2} \mathrm{Mn} \cdot 4 \mathrm{LiCl}$

Aluminum-TMP amides have proven to be especially useful for the metalation of electron-rich pyridines. Thus, the treatment of TMPLi with $\mathrm{AlCl}_{3}$ provides the corresponding $\mathrm{TMP}_{3} \mathrm{Al} \cdot 3 \mathrm{LiCl}$ base (141) as a $0.3 \mathrm{M}$ solution in THF. This base readily aluminates the 2-methoxypyridine 142 leading to the tris-arylaluminum 143, which provides, after transmetalation to zinc and to copper, and acylation, the expected ketone 144 in $90 \%$ yield (Scheme 28). ${ }^{56}$

The treatment of TMPMgCl$\cdot \mathrm{LiCl}$ with $\mathrm{LaCl}_{3} \cdot 2 \mathrm{LiCl}^{58,59}$ and its addition to a functionalized pyridine such as $\mathbf{1 1 5}$ leads to an organometallic intermediate best represented as $\mathbf{1 4 5}$. From recent results, ${ }^{59}$ the reagent 145 may be better represented as a magnesium reagent complexed with $\mathrm{LaCl}_{3}$, rather than a true aryllanthanum species. ${ }^{59}$ However, the reaction of $\mathbf{1 4 5}$ with the sterically hindered ketone 146 leads to the expected addition product 147 in $74 \%$ yield (Scheme 29). ${ }^{57}$ 


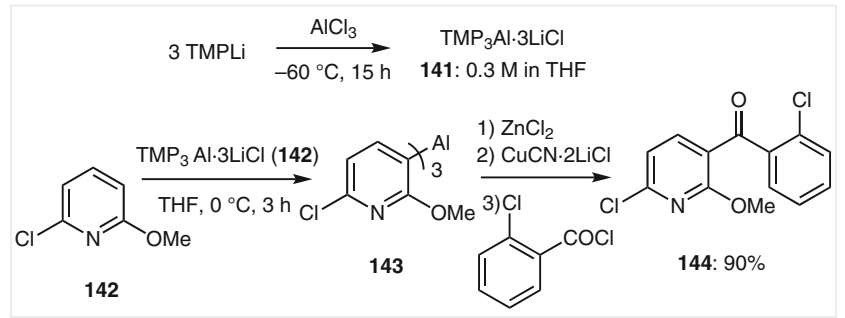

Scheme 28 Alumination of an electron-rich pyridine 142 using $\mathrm{TMP}_{3} \mathrm{Al} \cdot 3 \mathrm{LiCl}(\mathbf{1 4 1})$

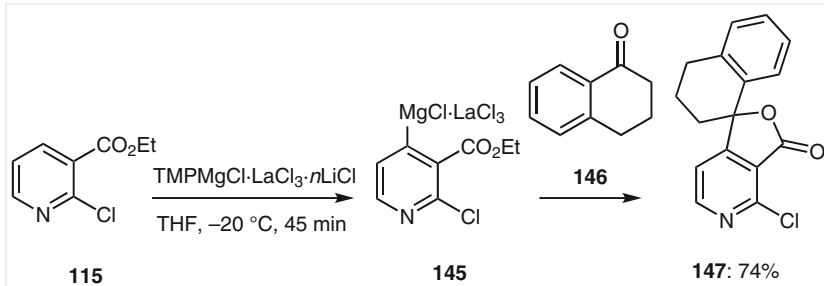

Scheme 29 Metalation of the functionalized pyridine $\mathbf{1 1 5}$ using $\mathrm{TMPMgCl} \cdot \mathrm{LaCl}_{3} \cdot \mathrm{nLiCl}$

\section{Magnesiation and Zincation of Diazines}

Whereas the metalation of pyridines and quinolones is relatively well explored, the metalation of diazines such as pyrimidine (148), pyrazine (149), and pyridazine (150) is much less studied, and the functionalization of these $\mathrm{N}$-heterocycles remains a challenge, as the predictability of the appropriate base for their metalation is still difficult (Figure 1).
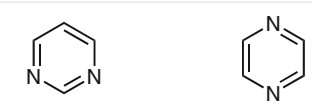

149: pyrazine

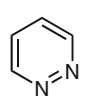

150: pyridazine
Figure 1 Diazine scaffolds

Nevertheless, the TMP-bases TMPMgCl.LiCl (1), $\mathrm{TMP}_{2} \mathrm{Mg} \cdot 2 \mathrm{LiCl}$ (34), TMPZnCl.LiCl (80) and $\mathrm{TMP}_{2} \mathrm{Zn} \cdot 2 \mathrm{Li}-$ $\mathrm{Cl} \cdot 2 \mathrm{MgCl}_{2}(\mathbf{8 1})$ have proven to be a set of very useful metalation reagents, especially well-suited for the functionalization of diazines and annulated analogues. These bases also constitute an automated strong base screening platform, as recently shown by Boga and Christensen. ${ }^{60}$ Some recent applications are shown below, as well as guidelines for rationalizing the metalations of various diazines. Whereas pyrimidine itself has a high propensity to add magnesium nucleophiles, substituted pyrimidines are better substrates for metalations. Thus, 2-bromopyrimidine (151) undergoes a smooth magnesiation with $\mathrm{TMPMgCl} \cdot \mathrm{LiCl}(\mathbf{1})$ at $-55^{\circ} \mathrm{C}$ within $1.5 \mathrm{~h}$ and produces the 4-magnesiated pyrimidine $\mathbf{1 5 2}$ in $>90 \%$ yield. After thiolation of $\mathbf{1 5 2}$ with $\mathrm{MeSO}_{2} \mathrm{SMe}$, the corresponding thioether $\mathbf{1 5 3}$ is obtained in $81 \%$ yield. ${ }^{61,62}$ The methylthio substituent has a highly stabiliz- ing effect and considerably stabilizes the pyrimidine towards unwanted nucleophilic additions. Thus, further magnesiation of $\mathbf{1 5 3}$ may now be performed at room temperature and the metalation is complete within $5 \mathrm{~min}$, producing the magnesiated pyrimidine $\mathbf{1 5 4}$, which, after chlorination, provides the trisubstituted pyrimidine $\mathbf{1 5 5}$ in $76 \%$ yield. The last position of the ring is magnesiated under similar conditions furnishing, after copper(I)-mediated benzoylation, the ketone $\mathbf{1 5 6}$ in $81 \%$ yield (Scheme 30). ${ }^{61}$
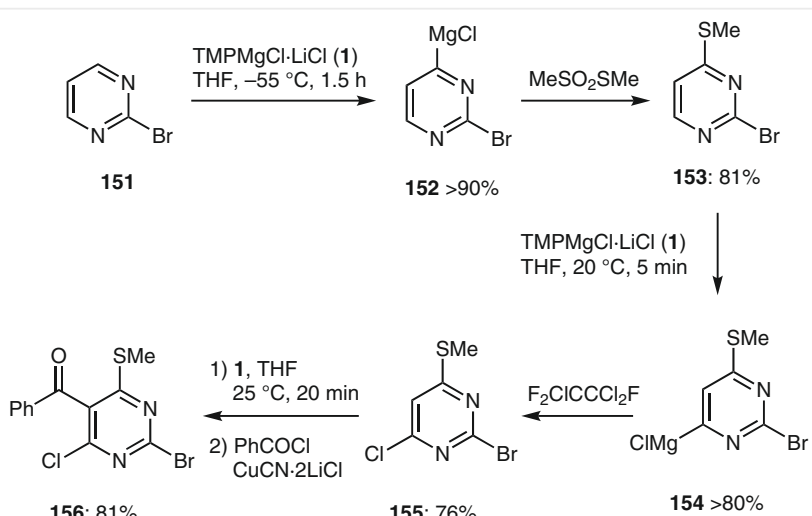

156: $81 \%$

155: $76 \%$

$154>80 \%$

Scheme 30 Regioselective magnesiations of 2-bromopyrimidine (151) using TMPMgCl.LiCl (1)

This methodology has been applied to the functionalization of 2-chloropyrimidine (157), providing a convenient synthesis of the fungicide mepanipyrim $158 .{ }^{63}$ Thus, the magnesiation of 157 at $-60{ }^{\circ} \mathrm{C}$ is complete within $2 \mathrm{~h}$ using $\mathrm{TMPMgCl} \cdot \mathrm{LiCl}(\mathbf{1})$. Transmetalation with $\mathrm{ZnCl}_{2}$ and iodolysis affords the bis-halogenated pyrimidine $\mathbf{1 5 9}$ in $91 \%$ yield. Subsequent magnesiation with TMPMgCl.LiCl $\left(\mathbf{1} ;-60{ }^{\circ} \mathrm{C}\right.$, $1 \mathrm{~h}$ ) followed by a bromination with 1,2-dibromotetrachloroethane affords the tri-halogenated pyrimidine $\mathbf{1 6 0}$ in almost quantitative yield (96\%). Negishi cross-coupling of the most reactive iodine-substituent at $\mathbf{1 6 0}$ using MeZnBr furnishes the pyrimidine $\mathbf{1 6 1}$ in 58\% yield. Sonogashira crosscoupling with propyne gives the alkynylpyrimidine $\mathbf{1 6 2}$ in $97 \%$ yield. Finally, Pd-catalyzed amination of $\mathbf{1 6 2}$ with aniline furnishes mepanipyrim 158 in $81 \%$ yield (Scheme 31). ${ }^{63}$

The amination of the pyrimidine scaffold can also be achieved using TMPMgCl.LiCl (1). Thus, the magnesiation of dichloropyrimidine 163 with 1 at $25{ }^{\circ} \mathrm{C}$ for $0.5 \mathrm{~h}$ produces the magnesium reagent $\mathbf{1 6 4}$. Its transmetalation with $\mathrm{CuCl} \cdot 2 \mathrm{LiCl}$ followed by the addition of $\mathrm{N}$-lithiomorpholine (165) leads to the lithium amidocuprate 166, which, after oxidative amination using chloranil, leads to the 5-aminopyrimidine $\mathbf{1 6 7}$ in $68 \%$ yield (Scheme 32). ${ }^{63,64}$

The regioselectivity of the metalation of uracil may be controlled by the bases used. ${ }^{65-67}$ Thus, the deprotonation of 2,4-dimethoxypyrimidine $\mathbf{1 6 8}$ with TMPLi proceeds through precomplexation of the lithium base at oxygen and leads to an ortho-lithiation (169). On the other hand, magnesiation with TMPMgCl.LiCl (1) in THF is triggered by a 
complexation of the magnesium base $\mathbf{1}$ at the heterocyclic $\mathrm{N}$-atom and therefore leads to a magnesiation at the orthoposition to nitrogen, providing the magnesium derivative 170. ${ }^{57}$ After quenching with ethyl cyanoformate, the uracil $\mathbf{1 7 1}$ is obtained in $71 \%$ yield. Subsequent magnesiation leads to $\mathbf{1 7 2}$ and a copper(I)-mediated benzoylation gives ketone $\mathbf{1 7 3}$ in 78\% yield (Scheme 33).67,68
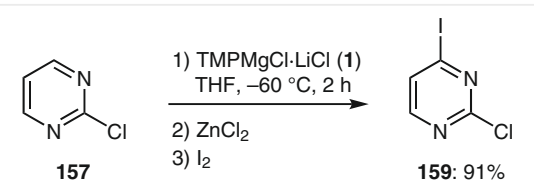

159: $91 \%$

$$
\mid \begin{aligned}
& \text { 1) } \mathrm{TMPMgCl} \cdot \mathrm{LiCl}(1) \\
& \mathrm{THF},-60{ }^{\circ} \mathrm{C}, 1 \mathrm{~h} \\
& \text { 2) }\left(\mathrm{BrCCl}_{2}\right)_{2} \\
& \mathrm{THF},-65{ }^{\circ} \mathrm{C}, 3 \mathrm{~h}
\end{aligned}
$$

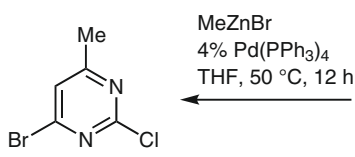

161: $58 \%$

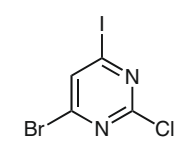

160: $96 \%$

$$
\mid \begin{aligned}
& \mathrm{Me}=\mathrm{H} \\
& 3 \% \mathrm{Pd}(0) \\
& 4 \% \mathrm{Cul} \\
& \mathrm{Et}_{3} \mathrm{~N}, 25^{\circ} \mathrm{C}, 1.5 \mathrm{~h}
\end{aligned}
$$

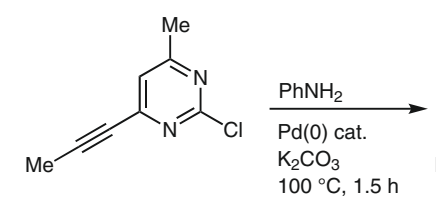

162: $97 \%$

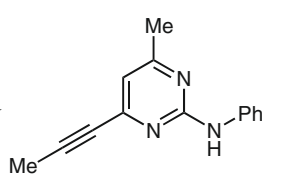

158: mepanipyrim, $81 \%$

Scheme 31 Synthesis of the fungicide mepanipyrim 158 starting from 2-chloropyrimidine (157) using TMPMgCl-LiCl (1)

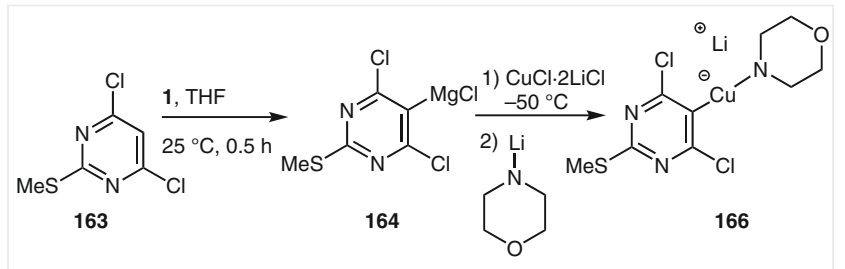<smiles>Cc1nc(Cl)c(ON2CCOCC2)c(Cl)n1</smiles>

Scheme 32 Amination of the pyrimidine scaffold using TMPMgCl.LiCl (1)

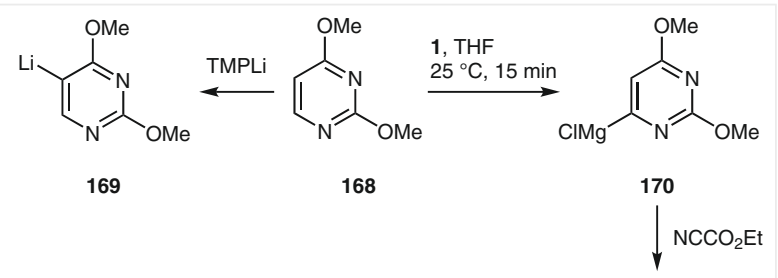<smiles>CCOC(=O)c1cc(OC)nc(OC)n1</smiles>

173: $78 \%$

172

171: $71 \%$

Scheme 33 Selective magnesiation of the protected uracil 168 using $\mathrm{TMPMgCl} \cdot \mathrm{LiCl}(\mathbf{1})$

The magnesiation of dichloropyrimidine $163\left(25^{\circ} \mathrm{C}\right.$, $0.5 \mathrm{~h}$ ) with $\mathrm{TMPMgCl} \cdot \mathrm{LiCl}$ (1) provides the magnesium derivative $\mathbf{1 6 4}$ as shown in Scheme 32. Its treatment with chiral sulfamidate $\mathbf{1 7 4}$ for $1 \mathrm{~h}$ at $25^{\circ} \mathrm{C}$ followed by acidification with trifluoroacetic acid (TFA) and heating with $\mathrm{Et}_{3} \mathrm{~N}$ (4 equiv) in MeCN for $0.5 \mathrm{~h}$ at $80{ }^{\circ} \mathrm{C}$ leads to the chiral heterocycle 175 in $85 \%$ yield. Using the sulfamidate 176 provides tetrahydropyridopyrimidine $\mathbf{1 7 7}$, which is a precursor for various unsaturated heterocycles (Scheme 34). ${ }^{69}$<smiles>COc1nc(Cl)c([N+](=O)[O-])c(Cl)n1</smiles><smiles>Cc1nc(Cl)c([N+](=O)[O-])c(Cl)n1</smiles>

Scheme 34 Preparation of annulated pyrimidine $\mathbf{1 7 5}$ and $\mathbf{1 7 7}$

The use of magnesium intermediates in some cases leads to rearrangements, ${ }^{70,71}$ as shown by the magnesiation of indolizine 178 using TMPMgCl$\cdot \mathrm{LiCl}(\mathbf{1})$ at $25^{\circ} \mathrm{C}$ for $1 \mathrm{~h}$. Under these conditions, a dynamic equilibrium between the two isomeric magnesium species 179 and $\mathbf{1 8 0}$ is observed. Whereas more reactive electrophiles such as iodine and aldehydes provide the products of type 181 , less reactive electrophiles such as $\mathrm{Cl}_{3} \mathrm{CCCl}_{3}$ or a Negishi crosscoupling provide products of type $\mathbf{1 8 2}$ (Scheme 35). ${ }^{70}$ 


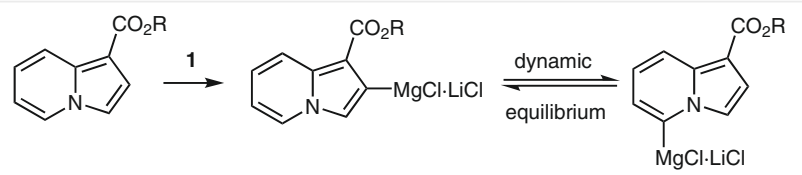

178

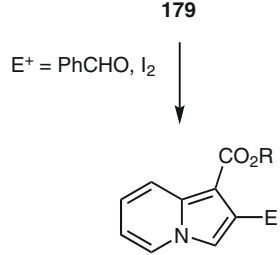

181
$\mathrm{E}^{+}=\underset{\mathrm{Arl}}{\mathrm{A}} \mathrm{Pd}(0)$ cat.
$\mathrm{Cl}_{3} \mathrm{CCl}_{3}$

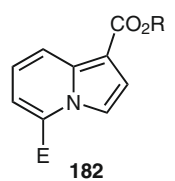

Scheme 35 Electrophile controlled regioselectivity in the functionalization of indolizine 178 using TMPMgCl. $\mathrm{LiCl}$ (1)

An in situ trapping procedure in several cases avoids side-reactions and provides high yields of products. Thus, the functionalization of the quinoxaline scaffold is possible using TMPLi. The treatment of dichloroquinoxaline 183 with TMPLi (2.4 equiv) in the presence of an excess of TMS$\mathrm{Cl}$ furnishes the bis-silyl derivative $\mathbf{1 8 4}$ in 74\% yield. After the addition of $\mathrm{ICl}$ ( 1 equiv) the mono-iodinated quinoxaline derivative 185 is obtained in $63 \%$ yield. ${ }^{72}$ Similarly, the 2,7-naphthyridine $\mathbf{1 8 6}$ can be converted into silyl derivative 187 in $73 \%$ yield (Scheme 36). ${ }^{73}$

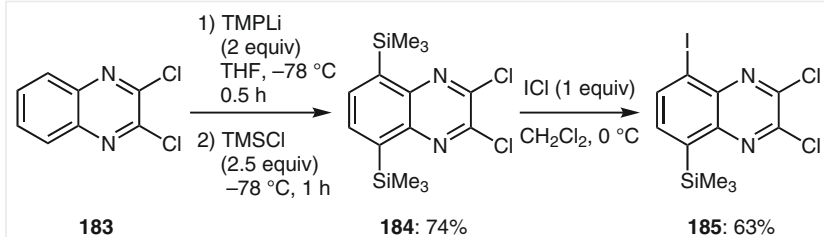

$$
\text { 2) } \mathrm{TMSCl}(1.2 \text { equiv) }
$$

187: $73 \%$

Scheme 36 Functionalization of quinoxalines and 2,7-naphthyridines using TMPLi

The 1,5-naphthyridine scaffold (188) has been examined in more detail. Complexation of $\mathrm{TMP}_{2} \mathrm{Mg} \cdot 2 \mathrm{LiCl}(\mathbf{3 4})$ to the nitrogen-atom $\mathrm{N} 1$ of $\mathbf{1 8 8}$ leads to a selective metalation in position C8. This magnesiation has to be performed at $78{ }^{\circ} \mathrm{C}$ (for $5 \mathrm{~min}$ ) to avoid decomposition of the metalated species. The resulting magnesium species 189 can be functionalized with various electrophiles $\mathrm{E}^{1} \mathrm{X}$ providing products of type 190. The mono-substituted naphthyridines $\mathbf{1 9 0}$ can be regioselectively functionalized using either TMPMg$\mathrm{Cl} \cdot \mathrm{LiCl}(\mathbf{1})$ or the combination of 1 and $\mathrm{BF}_{3} \cdot \mathrm{OEt}_{2}$. In the first case, complexation of the base $\mathbf{1}$ occurs at the sterically most accessible $\mathrm{N} 5$, leading to a magnesiation and thus functionalization at position C4 (191).
On the other hand, the addition of $\mathrm{BF}_{3} \cdot \mathrm{OEt}_{2}$ prior to the addition of $\mathbf{1}$ blocks a complexation of the magnesium base at N5 and, since N1 is also inaccessible due to the substituent $\mathrm{E}^{1}$, leads to a complexation of 1 to the $\mathrm{BF}_{3}$ unit and $\mathrm{a}$ deprotonation of the most acidic hydrogen at position C6. After quenching with an electrophile $\mathrm{E}^{2}-\mathrm{X}$ the disubstituted 1,5-naphthyridine 192 is obtained (Scheme 37). ${ }^{74}$ The products of type 192 may be further metalated, although a very strong lithium base (TMPLi) is required. Thus, the reaction of 192a with TMPLi at $-78{ }^{\circ} \mathrm{C}$ for $0.5 \mathrm{~h}$ provides the lithium intermediate 193, which is trapped with iodine, furnishing the adduct 194 in 70\% yield. The use of TMPLi also allows a fourth functionalization and the reaction of 194 with TMPLi at $-78{ }^{\circ} \mathrm{C}$ for $90 \mathrm{~s}$ (!) leads to an ortho-lithiation, providing the lithium reagent $\mathbf{1 9 5}$, which gives the more stable lithium derivative 196 through an intramolecular iodine-lithium exchange. After quenching with an electrophile such as an acid chloride in the presence of stoichiometric amounts of $\mathrm{CuCN} \cdot 2 \mathrm{LiCl}$, the corresponding ketone 197 is obtained in 70\% yield (Scheme 38). ${ }^{74}$ This methodology can be applied for the synthesis of an antibacterial agent such as 198. Thus, the magnesiation of 1,5-naphthyridine 188 with $\mathrm{TMP}_{2} \mathrm{Mg} \cdot 2 \mathrm{LiCl}$ (34) from -40 to $-20{ }^{\circ} \mathrm{C}$ for $4 \mathrm{~h}$, followed by a transmetalation with $\mathrm{ZnCl}_{2}$ and $\mathrm{Pd}(0)-$ catalyzed cross-coupling with 4-tert-butylphenyl iodide, provides the arylated naphthyridine 199 in 88\% yield. TMPLi-lithiation at position C4 followed by a methylation with methyl triflate affords the disubstituted naphthyridine $\mathbf{2 0 0}$ in 53\% yield. This naphthyridine can be converted into the antibacterial drug candidate 198 (Scheme 39). ${ }^{74,75}$

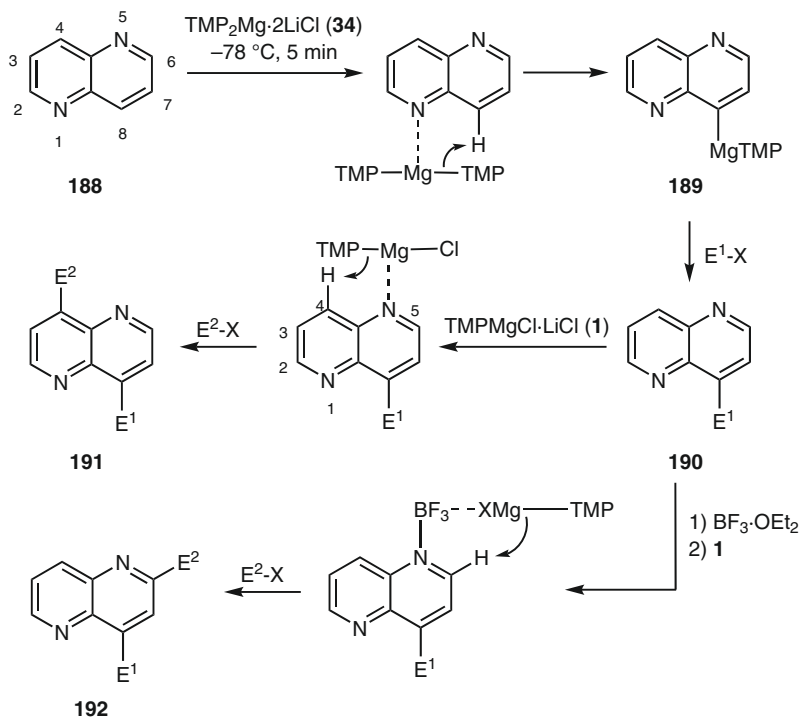

Scheme 37 Regioselective magnesiation and functionalization of 1,5-naphthyridines using $\mathrm{TMP}_{2} \mathrm{Mg} \cdot 2 \mathrm{LiCl}$ (34) and TMPMgCl$\cdot \mathrm{LiCl}$ (1) in the presence or absence of $\mathrm{BF}_{3} \cdot \mathrm{OEt}_{2}$ 

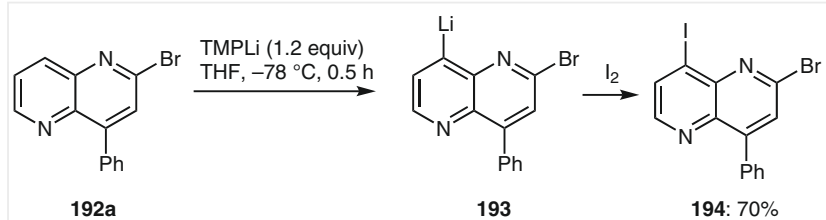<smiles>O=C(c1c(Br)cnc2c(-c3ccccc3)cc(Br)nc12)C1CC1</smiles>

197: $70 \%$

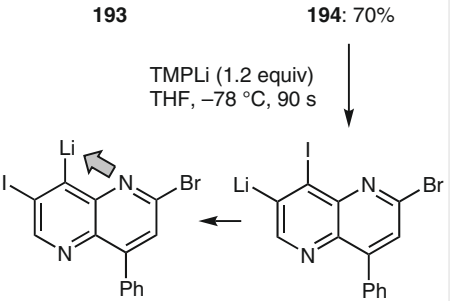

196

195
Scheme 38 Tri- and tetra-functionalization of 1,5-naphthyridines using TMPLi

TMPMgCl-LiCl (1) can be used to magnesiate highly functionalized 2,7-naphthyridines such as 201. Thus, the treatment of $\mathbf{2 0 1}$ triggered by a coordination at N2, affords the magnesium derivative 202, which undergoes an intramolecular addition to the carbethoxy function, providing the alkaloid sampangine $\mathbf{2 0 3}$ in 35\% yield (Scheme 40). ${ }^{76}$

Bracher has extended this strategy to a marine pyridoacridine alkaloid demethyldeoxyamphimedine (204). Thus, the magnesiation of ethyl nicotinate $\mathbf{2 0 5}$ with TMPMgCl.Li$\mathrm{Cl}(\mathbf{1})$ in the presence of $\mathrm{BF}_{3} \cdot \mathrm{OEt}_{2}$, followed by transmetalation with $\mathrm{ZnCl}_{2}$, furnishes the zinc reagent 206, which, after cross-coupling with 2-iodoaniline in the presence of a palladium-catalyst, furnishes the lactam 207 in $50 \%$ yield. Conversion into the corresponding bromide 208 using $\mathrm{POBr}_{3}$, followed by a second cross-coupling with the zincated ethyl nicotinate 206, produces the naphthyridine 209 in $78 \%$ yield. Cyclization of $\mathbf{2 0 9}$ with TMPMgCl. $\mathrm{TiCl}$ (1) furnishes the desired marine pyridoacridine alkaloid 204 in 28\% yield (Scheme 41). ${ }^{77}$

The metalation of the cinnoline scaffold (210) can also be realized using $\mathrm{TMP}_{2} \mathrm{Mg} \cdot 2 \mathrm{LiCl}$ (34). Thus, the reaction of 210 first with $\mathrm{BF}_{3} \cdot \mathrm{OEt}_{2}$, followed by the addition of $\mathrm{TMP}_{2} \mathrm{Mg} \cdot 2 \mathrm{LiCl}(\mathbf{3 4})$ at $-78{ }^{\circ} \mathrm{C}$ for $10 \mathrm{~min}$, leads to a regioselective magnesiation at $\mathrm{C} 3$. This regioselectivity can be

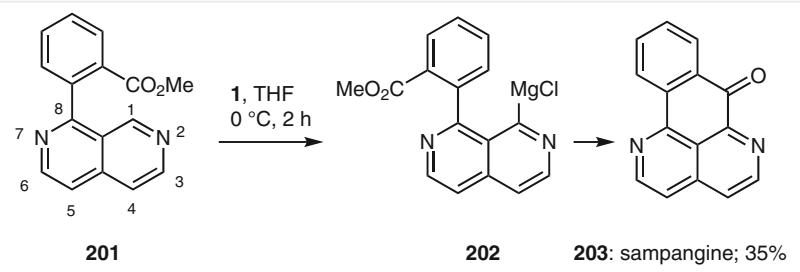

Scheme $40 \mathrm{TMPMgCl} \cdot \mathrm{LiCl}$ (1) magnesiation of the 2,7-naphthyridine 201 leading to the alkaloid sampangine 203
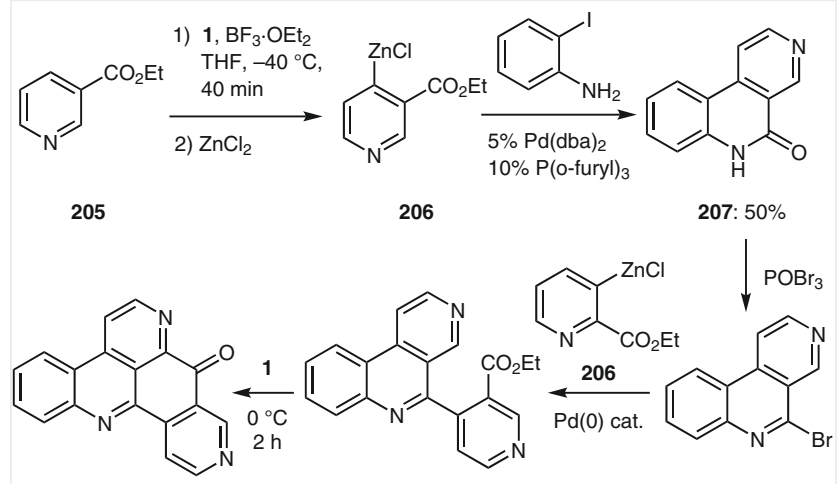

204: $28 \%$

209: $78 \%$

208: $59 \%$

Scheme 41 Preparation of the alkaloid demethyldeoxyamphimedine 204 using TMPMgCl.LiCl (1)

explained by assuming that $\mathrm{BF}_{3} \cdot \mathrm{OEt}_{2}$ complexes at the most readily available nitrogen $\mathrm{N} 2$ and that $\mathrm{TMP}_{2} \mathrm{Mg} \cdot 2 \mathrm{LiCl}$ coordinates at $\mathrm{BF}_{3}$ leading to a metalation at $\mathrm{C} 3$ (see 211). After $\operatorname{Pd}(0)$-catalyzed cross-couplings, the desired arylated products of type $\mathbf{2 1 2}$ are obtained. Alternatively, the metalation of 210 with $\mathrm{TMP}_{2} \mathrm{Zn} \cdot 2 \mathrm{LiCl} \cdot 2 \mathrm{MgCl}_{2}$ (49) in the presence of $\mathrm{MgCl}_{2}$ leads to a preferential complexation at $\mathrm{N1}$ of the base and at $\mathrm{N} 2$ of $\mathrm{MgCl}_{2}$, favoring a zincation at $\mathrm{C} 8$ via a transition state of type 213. After palladium-catalyzed arylation with various aryl iodides, 8-arylated cinnolines of type $\mathbf{2 1 4}$ are obtained (Scheme 42$).{ }^{78}$<smiles>c1cnc2cccnc2c1</smiles>

188

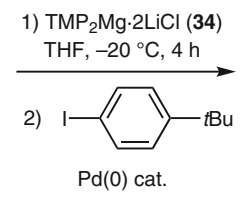

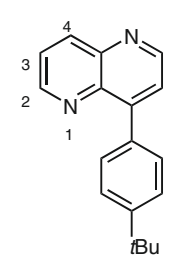

199: $88 \%$

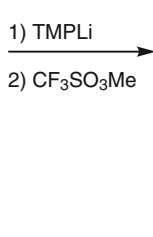

Scheme 39 Preparation of the antibacterial agent 198 through successive metalations of 1,5-naphthyridine 188

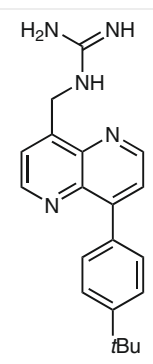

198 
<smiles>c1ccc2nnccc2c1</smiles>

1) $\mathrm{BF}_{3} \cdot \mathrm{OEt}_{2}$ 2) $\mathrm{TMP}_{2} \mathrm{Mg} \cdot 2 \mathrm{LCl}(34)$ 10

210 $\mathrm{TMP}_{2} \mathrm{Zn} \cdot \mathrm{MgCl}_{2} \cdot \mathrm{LiCl}$ (81) $-50{ }^{\circ} \mathrm{C}, 3 \mathrm{~h}$ $\downarrow$

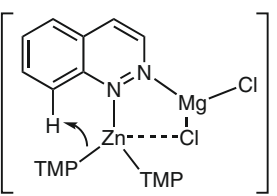
213 $-78^{\circ} \mathrm{C}, 10 \mathrm{~min}$

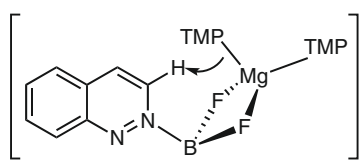

211

$$
\downarrow \begin{aligned}
& \operatorname{Ar}-\mathrm{I} \\
& \operatorname{Pd}(0) \text { cat. }
\end{aligned}
$$<smiles>Brc1cc2ccccc2nn1</smiles>

212: $60-75 \%$

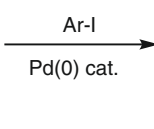<smiles>Brc1cccc2ccnnc12</smiles>

214: $60-85 \%$
Scheme 42 Regioselective metalation of the cinnoline scaffold using $\mathrm{TMP}_{2} \mathrm{Mg} \cdot 2 \mathrm{LiCl}$ (34) and $\mathrm{TMP}_{2} \mathrm{Zn} \cdot 2 \mathrm{LiCl} \cdot 2 \mathrm{MgCl}_{2}(\mathbf{8 1})$

As shown above, the presence or absence of a Lewis acid such as $\mathrm{BF}_{3} \cdot \mathrm{OEt}_{2}$ or $\mathrm{MgCl}_{2}$ is essential for achieving a high regioselectivity in metalations with TMP-bases. This has been demonstrated for various heterocyclic metalations. ${ }^{79-}$ ${ }^{81}$ Especially relevant in the frame of this review is the regioselective metalation of the pyrazine scaffold. Thus, the introduction of a bulky bis-trimethylsilylmethyl-substituent to the pyrazine core is readily realized by treating chloropyrazine $\mathbf{2 1 5}$ with the magnesium reagent 216. The resulting silyl-substituted pyrazine $\mathbf{2 1 7}$ proved to be difficult to magnesiate using TMP-magnesium bases such as 1 or $\mathbf{3 4}$. However, a precomplexation with $\mathrm{BF}_{3} \cdot \mathrm{OEt}_{2}$ sufficiently acidifies the ring hydrogen atoms, allowing a regioselective metalation at the least sterically hindered position at C5 (see $\mathbf{2 1 8}$, Scheme 43). ${ }^{81}$

The resulting magnesium reagent $\mathbf{2 1 9}$ reacts with various electrophiles. Chlorination with $\mathrm{PhSO}_{2} \mathrm{Cl}$ provides the chloropyrazine $\mathbf{2 2 0}$ in $61 \%$ yield. This pyrazine is readily magnesiated in a subsequent step. Remarkably, the inductive effect of the chlorine substituent is sufficient for a magnesiation to be achieved with $\mathrm{TMP}_{2} \mathrm{Mg} \cdot 2 \mathrm{LiCl}(34)$ in the absence of $\mathrm{BF}_{3} \cdot \mathrm{OEt}_{2}$. The resulting magnesiated pyrazine $\mathbf{2 2 1}$

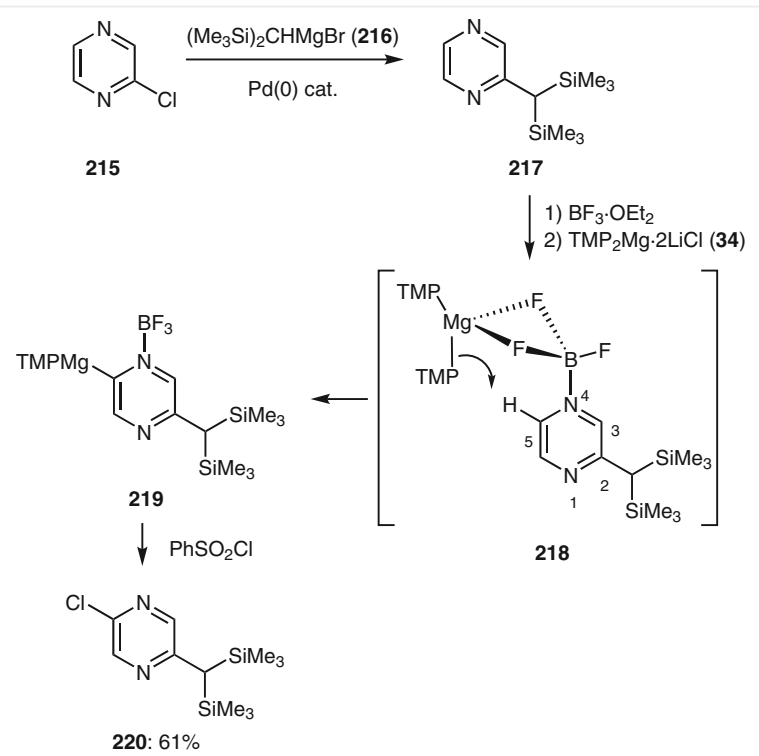

Scheme 43 Regioselective functionalization of the pyrazine scaffold

can be brominated with 1,2-dibromotetrachloroethane providing the bis-halogenated pyrazine $\mathbf{2 2 2}$ in 93\% yield. Finally, the last ring hydrogen of $\mathbf{2 2 2}$ can again be metalated with $\mathrm{TMP}_{2} \mathrm{Mg} \cdot 2 \mathrm{LiCl}$ (34), leading to the magnesium species 223, which, after iodolysis, provides the tri-halogenated pyrazine $\mathbf{2 2 4}$ in $\mathbf{8 3} \%$ yield (Scheme 44 ). ${ }^{81}$

The metalation of the pyrazine and the pyridazine scaffolds remains a challenge and usually quite strong bases are required for these metalations. Especially for the pyridazine scaffold, either yields are low or the electrophile scope is narrow. ${ }^{8 f, 9 a}$ The presence of two chlorine substituents in 3,6-dichloropyrazine $\mathbf{2 2 5}$ facilitates the metalation and now $\mathrm{TMP}_{2} \mathrm{Zn} \cdot 2 \mathrm{LiCl} \cdot 2 \mathrm{MgCl}_{2}(\mathbf{8 1})$ leads to a zincation at $-78{ }^{\circ} \mathrm{C} .82$ Also, a more convenient zincation of pyridazine 225 can be realized at $25^{\circ} \mathrm{C}$ with TMPZnCl. $\mathrm{LiCl}(\mathbf{8 0})$. The resulting zinc reagent $\mathbf{2 2 6}$ can be acylated after a transmetalation with $\mathrm{CuCN} \cdot 2 \mathrm{LiCl}$, leading to the corresponding ketone 227 (Scheme 45). ${ }^{45}$ Similarly, the corresponding dibromopyridazine $\mathbf{2 2 8}$ is zincated with TMPZnCl.LiCl (80) under the same conditions, furnishing the zincated heterocycle

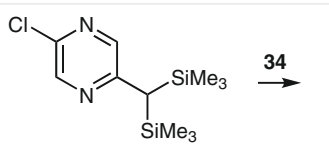

220<smiles>COc1nc(C(C)C)cnc1Cl</smiles>

221<smiles>CC(C)[C@H](C)c1cnc(Cl)c(Br)n1</smiles>

222: $93 \%$<smiles>CC(C)c1cnc(Cl)c(Br)n1</smiles>

222: $93 \%$<smiles>CC(C)c1nc(Br)c(Cl)nc1N=[W]</smiles>

223<smiles>CC(C)c1nc(Br)c(Cl)nc1I</smiles>

224: $83 \%$

Scheme 44 Successive magnesiation of the pyrazine scaffold using $\mathrm{TMP}_{2} \mathrm{Mg} \cdot 2 \mathrm{LiCl}$ (34) 
229, which is benzoated, after transmetalation with CuCN.2LiCl, leading to the ketone $\mathbf{2 3 0}$ in $86 \%$ yield (Scheme 45). ${ }^{46,83}$

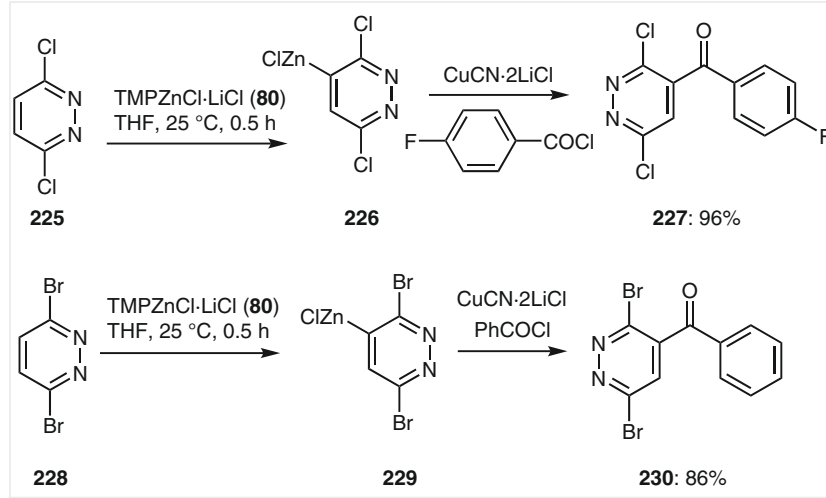

Scheme 45 Zincations of the halogenopyridazines 225 and 228

Finally, zinc-TMP-bases are especially efficient for the zincation of 2-pyridones and 2,7-naphthyridones. Thus, treatment of functionalized 2-pyridone 231 with $\mathrm{TMP}_{2} \mathrm{Zn} \cdot 2 \mathrm{LiCl}(\mathbf{8 1})$ at $-10{ }^{\circ} \mathrm{C}$ for $72 \mathrm{~h}$ leads to the zincated pyridone 232, which, after iodolysis, affords the iodopyridone $\mathbf{2 3 3}$ in $\mathbf{8 0 \%}$ yield. Similarly, naphthyridone $\mathbf{2 3 4}$ is zincated regioselectively and Pd-catalyzed cross-coupling with 4-iodoaniline provides the cross-coupling product 235 in $76 \%$ yield (Scheme 46 ). ${ }^{84}$

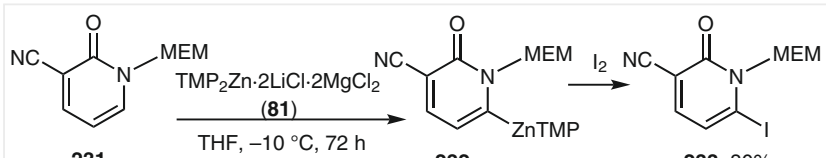<smiles>NC(=Nn1c(-c2ccc(N)cc2)cc2ccncc2c1=O)c1ccc(Br)cc1</smiles>

Scheme 46 Functionalization of 2-pyridones and 2-naphthyridones using $\mathrm{TMP}_{2} \mathrm{Zn} \cdot 2 \mathrm{LiCl} \cdot 2 \mathrm{MgCl}_{2}(\mathbf{8 1})$

\section{Conclusion}

The functionalization of azines and diazines is an important task for pharmaceutical and agro-chemical research. Herein, we have summarized recent developments in the field of azine metalation using TMPMgCl. $\mathrm{TiCl}(\mathbf{1})$, $\mathrm{TMP}_{2} \mathrm{Mg} \cdot 2 \mathrm{LiCl}$ (34), TMPZnCl.LiCl (80), and $\mathrm{TMP}_{2} \mathrm{Zn} \cdot 2 \mathrm{Li}-$ $\mathrm{Cl} \cdot 2 \mathrm{MgCl}_{2}(\mathbf{8 1})$, and have shown that they are excellent bases for the functionalization of $\mathrm{N}$-heterocycles. The additional use of $\mathrm{BF}_{3} \cdot \mathrm{OEt}_{2}$ or $\mathrm{MgCl}_{2}$ as Lewis acids considerably expands the scope of these bases. Furthermore, the performance of such metalations not in batch, but in continuous flow, allows further tuning of the reaction conditions, so that more convenient reaction temperatures and short reaction times can be achieved. In the future, the combination of these methods will certainly facilitate the functionalization of diazines and benzo-analogues further, since this research is still in its infancy.

\section{Funding Information}

We would like to thank the DFG (SFB749) for financial support

\section{Acknowledgment}

We would like to thank Albemarle (Hoechst, Germany) for the generous donation of chemicals.

\section{References}

(1) (a) Li, X.-Q.; Andersson, T. B.; Ahlström, M.; Weidolf, L. Drug Metab. Dispos. 2004, 32, 821. (b) Manolikakes, S. M.; Barl, N. M.; Sämann, C.; Knochel, P. Z. Naturforsch., B 2013, 68, 411. (c) Lamberth, C. Pest Manage. Sci. 2013, 69, 1106. (d) Dinesh, K.; Subheet, K. J. Curr. Med. Chem. 2016, 23, 4338. (e) Taylor, A. P.; Robinson, R. P.; Fobian, Y. M.; Blakemore, D. C.; Jones, L. H.; Fadeyi, O. Org. Biomol. Chem. 2016, 14, 6611.

(2) (a) Beak, P.; Snieckus, V. Acc. Chem. Res. 1982, 15, 306. (b) Snieckus, V. Chem. Rev. 1990, 90, 879. (c) Alessi, M.; Larkin, A. L.; Ogilvie, K. A.; Green, L. A.; Lai, S.; Lopez, S.; Snieckus, V. J. Org. Chem. 2007, 72, 1588. (d) Schneider, C.; Broda, E.; Snieckus, V. Org. Lett. 2011, 13, 3588. (e) Board, J.; Cosman, J. L.; Rantanen, T.; Singh, S. P.; Snieckus, V. Platinum Met. Rev. 2013, $57,234$.

(3) (a) Schlosser, M.; Jung, H. C.; Takagishi, S. Tetrahedron 1990, 46, 5633. (b) Marzi, E.; Bigi, A.; Schlosser, M. Eur.J. Org. Chem. 2001, 1371. (c) Schlosser, M. Eur. J. Org. Chem. 2001, 3975. (d) Schlosser, M.; Rausis, T. Eur. J. Org. Chem. 2004, 1018. (e) Schlosser, M. Angew. Chem. Int. Ed. 2005, 44, 376.

(4) (a) Marsais, F.; Queguiner, G. Tetrahedron 1983, 39, 2009. (b) Trécourt, F.; Mallet, M.; Marsais, F.; Queguiner, G. J. Org. Chem. 1988, 53, 1367. (c) Rocca, P.; Cochennec, C.; Marsais, F.; Thomas-dit-Dumont, L.; Mallet, M.; Godard, A.; Queguiner, G. J. Org. Chem. 1993, 58, 7832. (d) Trécourt, F.; Mallet, M.; Mongin, O.; Gervais, B.; Quéguiner, G. Tetrahedron 1993, 49, 8373. (e) Gros, P.; Fort, Y.; Queguiner, G.; Caubère, P. Tetrahedron Lett. 1995, 36, 4791. (f) Cochennec, C.; Rocca, P.; Marsais, F.; Godard, A.; Quéguiner, G. Synthesis 1995, 321. (g) Arzel, E.; Rocca, P.; Marsais, F.; Godard, A.; Quéguiner, G. Tetrahedron Lett. 1998, 39, 6465. (h) Mongin, F.; Quéguiner, G. Tetrahedron 2001, 57, 4059. (i) Turck, A.; Plé, N.; Mongin, F.; Quéguiner, G. Tetrahedron 2001, 57, 4489. (j) Awad, H.; Mongin, F.; Trécourt, F.; Quéguiner, G.; Marsais, F. Tetrahedron Lett. 2004, 45, 7873.

(5) (a) Chevallier, F.; Mongin, F. Chem. Soc. Rev. 2008, 37, 595. (b) Tilly, D.; Chevallier, F.; Mongin, F.; Gros, P. C. Chem. Rev. 2014, 114, 1207.

(6) Gros, P. C.; Fort, Y. Eur. J. Org. Chem. 2009, 4199.

(7) (a) Becker, M. R.; Knochel, P. Angew. Chem. Int. Ed. 2015, 54, 12501. (b) Ketels, M.; Konrad, D. B.; Karaghiosoff, K.; Trauner, D.; Knochel, P. Org. Lett. 2017, 19, 1666. 
(8) (a) Mulvey, R. E. Organometallics 2006, 25, 1060. (b) Mulvey, R. E.; Mongin, F.; Uchiyama, M.; Kondo, Y. Angew. Chem. Int. Ed. 2007, 46, 3802. (c) Mulvey, R. E. Acc. Chem. Res. 2009, 42, 743. (d) Armstrong, D. R.; Kennedy, A. R.; Mulvey, R. E.; Parkinson, J. A.; Robertson, S. D. Chem. Sci. 2012, 3, 2700. (e) Mulvey, R. E. Dalton Trans. 2013, 6676. (f) Uzelac, M.; Kennedy, A. R.; Hevia, E.; Mulvey, R. E. Angew. Chem. Int. Ed. 2016, 55, 13147.

(9) (a) Seggio, A.; Chevallier, F.; Vaultier, M.; Mongin, F. J. Org. Chem. 2007, 72, 6602. (b) L'Helgoual'ch, J.-M.; Bentabed-Ababsa, G.; Chevallier, F.; Yonehara, M.; Uchiyama, M.; Derdour, A.; Mongin, F. Chem. Commun. 2008, 5375. (c) Bentabed-Ababsa, G.; Blanco, F.; Derdour, A.; Mongin, F.; Trécourt, F.; Quéguiner, G.; Ballesteros, R.; Abarca, B. J. Org. Chem. 2009, 74, 163. (d) Nguyen, T. T.; Chevallier, F.; Jouikov, V.; Mongin, F. Tetrahedron Lett. 2009, 50, 6787. (e) Snégaroff, K.; L'Helgoual'ch, J.-M.; Bentabed-Ababsa, G.; Nguyen, T. T.; Chevallier, F.; Yonehara, M.; Uchiyama, M.; Derdour, A.; Mongin, F. Chem. Eur. J. 2009, 15, 10280. (f) Dayaker, G.; Chevallier, F.; Gros, P. C.; Mongin, F. Tetrahedron 2010, 66, 8904. (g) Snégaroff, K.; Komagawa, S.; Chevallier, F.; Gros, P. C.; Golhen, S.; Roisnel, T.; Uchiyama, M.; Mongin, F. Chem. Eur. J. 2010, 16, 8191. (h) Nguyen, T. T.; Marquise, N.; Chevallier, F.; Mongin, F. Chem. Eur. J. 2011, 17, 10405. (i) Nagaradja, E.; Chevallier, F.; Roisnel, T.; Jouikov, V.; Mongin, F. Tetrahedron 2012, 68, 3063. (j) Kadiyala, R. R.; Tilly, D.; Nagaradja, E.; Roisnel, T.; Matulis, V. E.; Ivashkevich, O. A.; Halauko, Y. S.; Chevallier, F.; Gros, P. C.; Mongin, F. Chem. Eur. J. 2013, 19, 7944. (k) Marquise, N.; Harford, P. J.; Chevallier, F.; Roisnel, T.; Dorcet, V.; Gagez, A.-L.; Sablé, S.; Picot, L.; Thiéry, V.; Wheatley, A. E. H.; Gros, P. C.; Mongin, F. Tetrahedron 2013, 69, 10123. (l) Harford, P. J.; Peel, A. J.; Chevallier, F.; Takita, R.; Mongin, F.; Uchiyama, M.; Wheatley, A. E. H. Dalton Trans. 2014, 14181. (m) Marquise, N.; Bretel, G.; Lassagne, F.; Chevallier, F.; Roisnel, T.; Dorcet, V.; Halauko, Y. S.; Ivashkevich, O. A.; Matulis, V. E.; Gros, P. C.; Mongin, F. RSC Adv. 2014, 4, 19602. (n) Messaoud, M. Y. A.; Bentabed-Ababsa, G.; Hedidi, M.; Derdour, A.; Chevallier, F.; Halauko, Y. S.; Ivashkevich, O. A.; Matulis, V. E.; Picot, L.; Thiéry, V.; Roisnel, T.; Dorcet, V.; Mongin, F. Beilstein J. Org. Chem. 2015, 11, 1475. (o) Nagaradja, E.; Bentabed-Ababsa, G.; Scalabrini, M.; Chevallier, F.; Philippot, S.; Fontanay, S.; Duval, R. E.; Halauko, Y. S.; Ivashkevich, O. A.; Matulis, V. E.; Roisnel, T.; Mongin, F. Bioorg. Med. Chem. 2015, 23, 6355. (p) Hedidi, M.; Bentabed-Ababsa, G.; Derdour, A.; Halauko, Y. S.; Ivashkevich, O. A.; Matulis, V. E.; Chevallier, F.; Roisnel, T.; Dorcet, V.; Mongin, F. Tetrahedron 2016, 72, 2196. (q) Hedidi, M.; Erb, W.; Lassagne, F.; Halauko, Y. S.; Ivashkevich, O. A.; Matulis, V. E.; Roisnel, T.; Bentabed-Ababsa, G.; Mongin, F. RSC Adv. 2016, 6, 63185. (r) Peel, A. J.; Hedidi, M.; BentabedAbabsa, G.; Roisnel, T.; Mongin, F.; Wheatley, A. E. H. Dalton Trans. 2016, 6094.

(10) (a) Kondo, Y.; Shilai, M.; Uchiyama, M.; Sakamoto, T. J. Am. Chem. Soc. 1999, 121, 3539. (b) Imahori, T.; Uchiyama, M.; Sakamoto, T.; Kondo, Y. Chem. Commun. 2001, 2450. (c) Uchiyama, M.; Miyoshi, T.; Kajihara, Y.; Sakamoto, T.; Otani, Y.; Ohwada, T.; Kondo, Y. J. Am. Chem. Soc. 2002, 124, 8514. (d) Tezuka, N.; Shimojo, K.; Hirano, K.; Komagawa, S.; Yoshida, K.; Wang, C.; Miyamoto, K.; Saito, T.; Takita, R.; Uchiyama, M. J. Am. Chem. Soc. 2016, 138, 9166.

(11) Imahori, T.; Kondo, Y.J. Am. Chem. Soc. 2003, 125, 8082.

(12) (a) Haag, B.; Mosrin, M.; Ila, H.; Malakhov, V.; Knochel, P. Angew. Chem. Int. Ed. 2011, 50, 9794. (b) Krasovskiy, A.; Krasovskaya, V.; Knochel, P. Angew. Chem. Int. Ed. 2006, 45, 2958. (c) Klatt, T.; Markiewicz, J. T.; Sämann, C.; Knochel, P. J. Org. Chem. 2014, 79, 4253.
(13) García-Álvarez, P.; Graham, D. V.; Hevia, E.; Kennedy, A. R.; Klett, J.; Mulvey, R. E.; O'Hara, C. T.; Weatherstone, S. Angew. Chem. Int. Ed. 2008, 47, 8079.

(14) Wunderlich, S.; Knochel, P. Org. Lett. 2008, 10, 4705.

(15) For recent reviews on C-H activation, see: (a) Chen, Z.; Wang, B.; Zhang, J.; Yu, W.; Liu, Z.; Zhang, Y. Org. Chem. Front. 2015, 2, 1107. (b) Crabtree, R. H.; Lei, A. Chem. Rev. 2017, 117, 8481. (c) Murakami, K.; Yamada, S.; Kaneda, T.; Itami, K. Chem. Rev. 2017, 117, 9302.

(16) For previous reviews, see: (a) Bresser, T.; Mosrin, M.; Monzon, G.; Knochel, P. J. Org. Chem. 2010, 75, 4686. (b) Knochel, P.; Schade, M. A.; Bernhardt, S.; Manolikakes, G.; Metzger, A.; Piller, F. M.; Rohbogner, C. J.; Mosrin, M. Beilstein J. Org. Chem. 2011, 7, 1261. (c) Manolikakes, S. M.; Barl, N. M.; Sämann, C.; Knochel, P. Z. Naturforsch., B 2013, 68, 411. (d) Klatt, T.; Markiewicz, J. T.; Sämann, C.; Knochel, P. J. Org. Chem. 2014, 79, 4253.

(17) (a) Hauser, C. R.; Walker, H. G. J. Am. Chem. Soc. 1947, 69, 295. (b) Henderson, K. W.; Kerr, W. J. Chem. Eur. J. 2001, 7, 3430. (c) Eaton, P. E.; Xiong, Y.; Gilardi, R. J. Am. Chem. Soc. 1993, 115, 10195. (d) Eaton, P. E.; Lukin, K. A. J. Am. Chem. Soc. 1993, 115, 11370. (e) Zhang, M.-X.; Eaton, P. E. Angew. Chem. Int. Ed. 2002, $41,2169$.

(18) (a) Schlecker, W.; Huth, A.; Ottow, E.; Mulzer, J. J. Org. Chem. 1995, 60, 8414. (b) Schlecker, W.; Huth, A.; Ottow, E.; Mulzer, J. Liebigs Ann. 1995, 1441. (c) Schlecker, W.; Huth, A.; Ottow, E.; Mulzer, J. Synthesis 1995, 1225.

(19) (a) Gribble, G. W.; Saulnier, M. G. Tetrahedron Lett. 1980, 21, 4137. (b) Verbeek, J.; Brandsma, L. J. Org. Chem. 1984, 49, 3857. (c) Verbeek, J.; George, A. V. E.; de Jong, R. L. P.; Brandsma, L. J. Chem. Soc., Chem. Commun. 1984, 257. (d) Subota, A. I.; Grygorenko, O. O.; Valter, Y. B.; Tairov, M. A.; Artamonov, O. S.; Volochnyuk, D. M.; Ryabukhin, S. V. Synlett 2015, 26, 408.

(20) In the case of a stabilized pyridine such as 2-methoxy pyridine, higher temperatures are possible, see: (a) Trecourt, F.; Mallet, M.; Marsais, F.; Queguiner, G. J. Org. Chem. 1988, 53, 1367. (b) Khartabil, H. K.; Gros, P. C.; Fort, Y.; Ruiz-López, M. F. J. Am. Chem. Soc. 2010, 132, 2410; and ref. 4d.

(21) Boudet, N.; Lachs, J. R.; Knochel, P. Org. Lett. 2007, 9, 5525.

(22) Wunderlich, S. H.; Rohbogner, C. J.; Unsinn, A.; Knochel, P. Org. Process Res. Dev. 2010, 14, 339.

(23) Negishi, E. Acc. Chem. Res. 1982, 15, 340.

(24) Haas, D.; Hammann, J. M.; Greiner, R.; Knochel, P. ACS Catal. 2016, 6, 1540.

(25) Monzón, G.; Tirotta, I.; Nishii, Y.; Knochel, P. Angew. Chem. Int. Ed. 2012, 51, 10624.

(26) (a) Ogawa, S.; Furukawa, N. J. Org. Chem. 1991, 56, 5723. (b) Capozzi, M. A. M.; Cardellicchio, C.; Naso, F.; Spina, G.; Tortorella, P. J. Org. Chem. 2001, 66, 5933.

(27) (a) Rauhut, C. B.; Melzig, L.; Knochel, P. Org. Lett. 2008, 10, 3891. (b) Melzig, L.; Rauhut, C. B.; Knochel, P. Synthesis 2009, 1041. (c) Melzig, L.; Rauhut, C. B.; Knochel, P. Chem. Commun. 2009, 3536.

(28) Melzig, L.; Rauhut, C. B.; Naredi-Rainer, N.; Knochel, P. Chem. Eur. J. 2011, 17, 5362.

(29) MacNeil, S. L.; Familoni, O. B.; Snieckus, V.J. Org. Chem. 2001, 66, 3662.

(30) Balkenhohl, M.; François, C.; Sustac, R. D.; Quinio, P.; Knochel, P. Org. Lett. 2017, 19, 536.

(31) Tran, L. D.; Daugulis, O. Org. Lett. 2010, 12, 4277.

(32) Rohbogner, C. J.; Clososki, G. C.; Knochel, P. Angew. Chem. Int. Ed. 2008, 47, 1503.

(33) Rohbogner, C. J.; Wirth, S.; Knochel, P. Org. Lett. 2010, 12, 1984. 
(34) Sorbera, L. A.; Castaner, R. M.; Silvestre, J.; Castaner, J. Drugs Future 2001, 26, 346.

(35) Milne, J. E.; Buchwald, S. L. J. Am. Chem. Soc. 2004, 126, 13028.

(36) (a) Milstein, D.; Stille, J. K. J. Am. Chem. Soc. 1978, 100, 3636. (b) Cordovilla, C.; Bartolomé, C.; Martínez-Ilarduya, J. M.; Espinet, P. ACS Catal. 2015, 5, 3040.

(37) Clososki, G. C.; Rohbogner, C. J.; Knochel, P. Angew. Chem. Int. Ed. 2007, 46, 7681.

(38) Farina, V.; Krishnan, B. J. Am. Chem. Soc. 1991, 113, 9585.

(39) Rohbogner, C. J.; Wunderlich, S. H.; Clososki, G. C.; Knochel, P. Eur. J. Org. Chem. 2009, 1781.

(40) Jaric, M.; Haag, B. A.; Unsinn, A.; Karaghiosoff, K.; Knochel, P. Angew. Chem. Int. Ed. 2010, 49, 5451.

(41) Manolikakes, S. M.; Jaric, M.; Karaghiosoff, K.; Knochel, P. Chem. Commun. 2013, 2124.

(42) Jaric, M.; Haag, B. A.; Manolikakes, S. M.; Knochel, P. Org. Lett. 2011, 13, 2306.

(43) Klatt, T.; Werner, V.; Maximova, M. G.; Didier, D.; Apeloig, Y.; Knochel, P. Chem. Eur. J. 2015, 21, 7830.

(44) Wunderlich, S. H.; Knochel, P. Angew. Chem. Int. Ed. 2007, 46, 7685.

(45) Mosrin, M.; Knochel, P. Org. Lett. 2009, 11, 1837.

(46) Bresser, T.; Monzon, G.; Mosrin, M.; Knochel, P. Org. Process Res. Dev. 2010, 14, 1299.

(47) Gosselin, F.; Savage, S. J.; Blaquiere, N.; Staben, S. T. Org. Lett. 2012, 14, 862 .

(48) McDonald, S. L.; Hendrick, C. E.; Wang, Q. Angew. Chem. Int. Ed. 2014, 53, 4667.

(49) McDonald, S. L.; Hendrick, C. E.; Bitting, K. J.; Wang, Q. Org. Synth. 2015, 92, 356.

(50) Manolikakes, S. M.; Ellwart, M.; Stathakis, C. I.; Knochel, P. Chem. Eur. J. 2014, 20, 12289.

(51) Chen, Y.-H.; Graßl, S.; Knochel, P. Angew. Chem. Int. Ed. 2018, 57, 1108.

(52) Castelló-Micó, A.; Knochel, P. Synthesis 2018, 50, 155.

(53) Frischmuth, A.; Fernández, M.; Barl, N. M.; Achrainer, F.; Zipse, H.; Berionni, G.; Mayr, H.; Karaghiosoff, K.; Knochel, P. Angew. Chem. Int. Ed. 2014, 53, 7928.

(54) Becker, M. R.; Ganiek, M. A.; Knochel, P. Chem. Sci. 2015, 6, 6649.

(55) (a) Wunderlich, S. H.; Kienle, M.; Knochel, P. Angew. Chem. Int. Ed. 2009, 48, 7256. (b) Wunderlich, S. H.; Bresser, T.; Dunst, C.; Monzon, G.; Knochel, P. Synthesis 2010, 2670. (c) Haas, D.; Hammann, J. M.; Moyeux, A.; Cahiez, G.; Knochel, P. Synlett 2015, 26, 1515.

(56) Wunderlich, S. H.; Knochel, P. Angew. Chem. Int. Ed. 2009, 48, 1501.

(57) Wunderlich, S. H.; Knochel, P. Chem. Eur. J. 2010, 16, 3304.

(58) Krasovskiy, A.; Kopp, F.; Knochel, P. Angew. Chem. Int. Ed. 2006, $45,497$.
(59) Benischke, A. D.; Anthore-Dalion, L.; Berionni, G.; Knochel, P. Angew. Chem. Int. Ed. 2017, 56, 16390.

(60) Boga, S. B.; Christensen, M.; Perrotto, N.; Krska, S. W.; Dreher, S.; Tudge, M. T.; Ashley, E. R.; Poirier, M.; Reibarkh, M.; Liu, Y.; Streckfuss, E.; Campeau, L.-C.; Ruck, R. T.; Davies, I. W.; Vachal, P. React. Chem. Eng. 2017, 2, 446.

(61) Mosrin, M.; Knochel, P. Org. Lett. 2008, 10, 2497.

(62) Mosrin, M.; Petrera, M.; Knochel, P. Synthesis 2008, 3697.

(63) Mosrin, M.; Knochel, P. Chem. Eur. J. 2009, 15, 1468.

(64) Del Amo, V.; Dubbaka, S. R.; Krasovskiy, A.; Knochel, P. Angew. Chem. Int. Ed. 2006, 45, 7838.

(65) Wada, A.; Yamamoto, J.; Kanatomo, S. Heterocycles 1987, 26, 585.

(66) Turck, A.; Plé, N.; Quéguiner, G. Heterocycles 1994, 37, 2149.

(67) Mosrin, M.; Boudet, N.; Knochel, P. Org. Biomol. Chem. 2008, 6, 3237.

(68) Soorukram, D.; Boudet, N.; Malakhov, V.; Knochel, P. Synthesis 2007, 3915 .

(69) Moss, T. A.; Hayter, B. R.; Hollingsworth, I. A.; Nowak, T. Synlett 2012, 23, 2408.

(70) Amaral, M. F. Z. J.; Baumgartner, A. A.; Vessecchi, R.; Clososki, G. C. Org. Lett. 2015, 17, 238.

(71) Barl, N. M.; Sansiaume-Dagousset, E.; Karaghiosoff, K.; Knochel, P. Angew. Chem. Int. Ed. 2013, 52, 10093.

(72) Nafe, J.; Herbert, S.; Auras, F.; Karaghiosoff, K.; Bein, T.; Knochel, P. Chem. Eur. J. 2015, 21, 1102.

(73) Greiner, R.; Blanc, R.; Petermayer, C.; Karaghiosoff, K.; Knochel, P. Synlett 2016, 27, 231.

(74) Balkenhohl, M.; Greiner, R.; Makarov, I. S.; Heinz, B.; Karaghiosoff, K.; Zipse, H.; Knochel, P. Chem. Eur. J. 2017, 23, 13046.

(75) Ioannidou, H. A.; Martin, A.; Gollner, A.; Koutentis, P. A. J. Org. Chem. 2011, 76, 5113.

(76) Plodek, A.; König, M.; Bracher, F. Eur. J. Org. Chem. 2015, 1302.

(77) Melzer, B.; Plodek, A.; Bracher, F. J. Org. Chem. 2014, 79, 7239.

(78) Klatt, T.; Roman, D. S.; León, T.; Knochel, P. Org. Lett. 2014, 16, 1232.

(79) Klier, L.; Aranzamendi, E.; Ziegler, D.; Nickel, J.; Karaghiosoff, K.; Carell, T.; Knochel, P. Org. Lett. 2016, 18, 1068.

(80) Klier, L.; Bresser, T.; Nigst, T. A.; Karaghiosoff, K.; Knochel, P. J. Am. Chem. Soc. 2012, 134, 13584.

(81) Groll, K.; Manolikakes, S. M.; du Jourdin, X. M.; Jaric, M.; Bredihhin, A.; Karaghiosoff, K.; Carell, T.; Knochel, P. Angew. Chem. Int. Ed. 2013, 52, 6776.

(82) Wunderlich, S.; Knochel, P. Chem. Commun. 2008, 6387.

(83) Unsinn, A.; Ford, M. J.; Knochel, P. Org. Lett. 2013, 15, 1128.

(84) Ziegler, D. S.; Greiner, R.; Lumpe, H.; Kqiku, L.; Karaghiosoff, K.; Knochel, P. Org. Lett. 2017, 19, 5760. 